Storms, E., Measurements of excess heat from a Pons-Fleischmann-type electrolytic cell using palladium sheet. Fusion Technol., 1993. 23: p. 230.

\title{
MEASUREMENTS OF EXCESS HEAT FROM A PONS- FLEISCHMANN-TYPE ELECTROLYTIC CELL USING PALLADIUM SHEET
}

\author{
EDMUND STORMS \\ Los Alamos National Laboratory NMT Division, Los Alamos, New Mexico 87545
}

KEYWORDS: excess heat measurement, calorimetry, palladium

Received July 27, 1992

Accepted for Publication September 28, 1992

Two pieces of palladium sheet similar to that used by Takahashi were loaded with deuterium in a Pons-Fleischmann-type electrolytic cell, and heat production was measured. One sheet produced a steady increase in excess power that reached $7.5 \mathrm{~W}$ (20\% of input power) before the study was interrupted. A second similar sheet from a different batch of palladium did not produce any measurable excess power. There were differences in the loading behavior, the maximum stoichiometry, and the presence of excess volume in the deuteride made from these materials. The first sheet contained $0.8 \%$ excess volume after having been deloaded from its maximum deuterium/palladium $(\mathrm{D} / \mathrm{Pd}$ ) ratio of 0.82 to 0.73 , and the second sheet contained $13.5 \%$ excess volume while at its maximum ratio of 0.75 . The high excess volume in the latter case is an indication of internal escape paths that reduce the required high D/Pd ratio.

\section{INTRODUCTION}

A computer-controlled, sealed, isoperibol-type calorimeter has been constructed to study the Pons-Fleischmann effect. This device will be used to study a variety of cathode materials, but its first use was the study of palladium sheets supplied by Tanaka Kikinzoku Kogyo K. K. to A. Takahashi of Osaka University. Single samples of palladium sheet from two different batches were studied. ${ }^{\text {a }}$

Takahashi reported $^{1}$ the production of excess power that exceeded $100 \mathrm{~W} / \mathrm{cm}^{3}$ (average of 1.7 $\times$ input power) from a Pons-Fleischmann-type electrolytic cell using this material. In addition to this extraordinary energy production, low-level neutron emission was measured that was roughly proportional to the magnitude of heat production when the cell current was changed, and it decreased with time.

In addition to using this unique palladium, Takahashi has suggested two procedures for success. The arrangement between the cathode and anode should produce uniform loading of the palladium sheet with deuterium, and the cathode should be subjected to periodic changes in cell current. He reports that excess energy increased with time when these procedures were used.

\footnotetext{
${ }^{\text {a }}$ The palladium sheets were transferred through R. George and E. Mallove.
} 
In addition to this recent success, excess heat production has also been reported in a significant number of studies ${ }^{2-28}$ using a variety of procedures and calorimeter designs; these studies found, in most cases, many positive results. Palladium rods were studied in most of this work, in contrast to the plate-shaped cathode used here.

Because relatively large amounts of excess heat are expected, a calorimeter design having a relatively low sensitivity but a high upper power limit was chosen. In addition, a design having simplicity of operation and calibration was used in order to reduce the various objections raised by critics of the cold fusion effect. Active stirring and temperature readings at two levels within the cell were used to eliminate the effect of possible temperature gradients. Four different calibration procedures were used, and these were applied before, during, and after the production of excess energy. The primary calibration used electrolytic heating of the LiOD electrolyte with a platinum cathode and anode. Except for chemical heat that might be associated with palladium, this method had the same bubble pattern, heat distribution, and chemical effects within the electrolyte as would be found in the cold fusion cell. In addition, this method produced a calibration constant similar to that determined when "dead" palladium was used as the cathode. Consequently, most of the objections raised to discount excess heat production are eliminated because they are canceled out by the calibration procedure. Because the calorimeter contained a recombiner, it could be completely sealed and pressurized with deuterium gas, and the internal pressure could be monitored. In this way, no material entered or left the cell under normal conditions. Significant excess heat was observed using these methods.

This technical note concentrates on the verification of excess heat and the measurement of various physical and chemical factors that are thought to be associated with excess energy production. No data or theories are presented about the possible source of heat or associated nuclear products other than to note that no tritium was produced.

\section{EXPERIMENTAL}

\section{II.A. Palladium Characterization}

The palladium sheets were weighed $( \pm 0.0001 \mathrm{~g})$, the dimensions were measured $( \pm 0.002 \mathrm{~cm})$, and the sheets were washed with acetone. When the metal had to be removed from the electrolytic cell for extended periods, it was placed in liquid nitrogen. Table I lists the physical measurements made before the calorimeter study.

\section{TABLE I}

Result of Physical Measurements Made Before the Study

\begin{tabular}{|c|c|c|c|c|c|}
\hline & $\begin{array}{c}\text { Weight } \\
\mathbf{( g )}\end{array}$ & $\begin{array}{c}\text { Area } \\
\left(\mathbf{c m}^{\mathbf{2}}\right)\end{array}$ & $\begin{array}{c}\text { Volume } \\
\left(\mathbf{c m}^{\mathbf{3}}\right)\end{array}$ & $\begin{array}{c}\text { Density } \\
\left(\mathbf{g} / \mathbf{c m}^{\mathbf{3}}\right)\end{array}$ & Surface \\
\hline Palladium sheet 1 & 3.9186 & 6.643 & 0.3358 & 11.670 & Smooth \\
Palladium sheet 2 & 3.8915 & 6.575 & 0.3273 & 11.889 & Fine parallel lines \\
\hline
\end{tabular}




\section{II.B. Calorimeter Description}

Figure 1 shows a cross section of the closed Pyrex glass calorimeter. A Teflon plug is held into a standard taper by a spring that allows pressure release should the internal pressure rise above $1.5 \mathrm{~atm}$. Holes through this plug give access for various probes. The calorimeter is attached to a sealed gas-handling system that maintains an overpressure of $\mathrm{D}_{2}$ and allows the pressure to be monitored. An additional sheet of platinum (counterelectrode) within the electrolyte provided the means to calibrate the cell without disturbing the palladium and to conduct heat generated at the recombiner into the electrolyte. Later in the study, this feature was eliminated without producing a change in the calibration constant. The recombiner is carbon cloth impregnated with Teflon and platinum. A Teflon-covered magnet is used for active stirring.

Figure 2 shows the electrical connections to the data acquisition system, and Fig. 3 shows the position of the various access probes into the calorimeter. Two thermocouples monitor the top and bottom of the electrolyte, a glass-encased Joule heater is used for calibration, and a capillary, placed within $0.5 \mathrm{~mm}$ of the cathode surface, monitors the voltage between the cathode and an external platinum electrode (reference electrode).

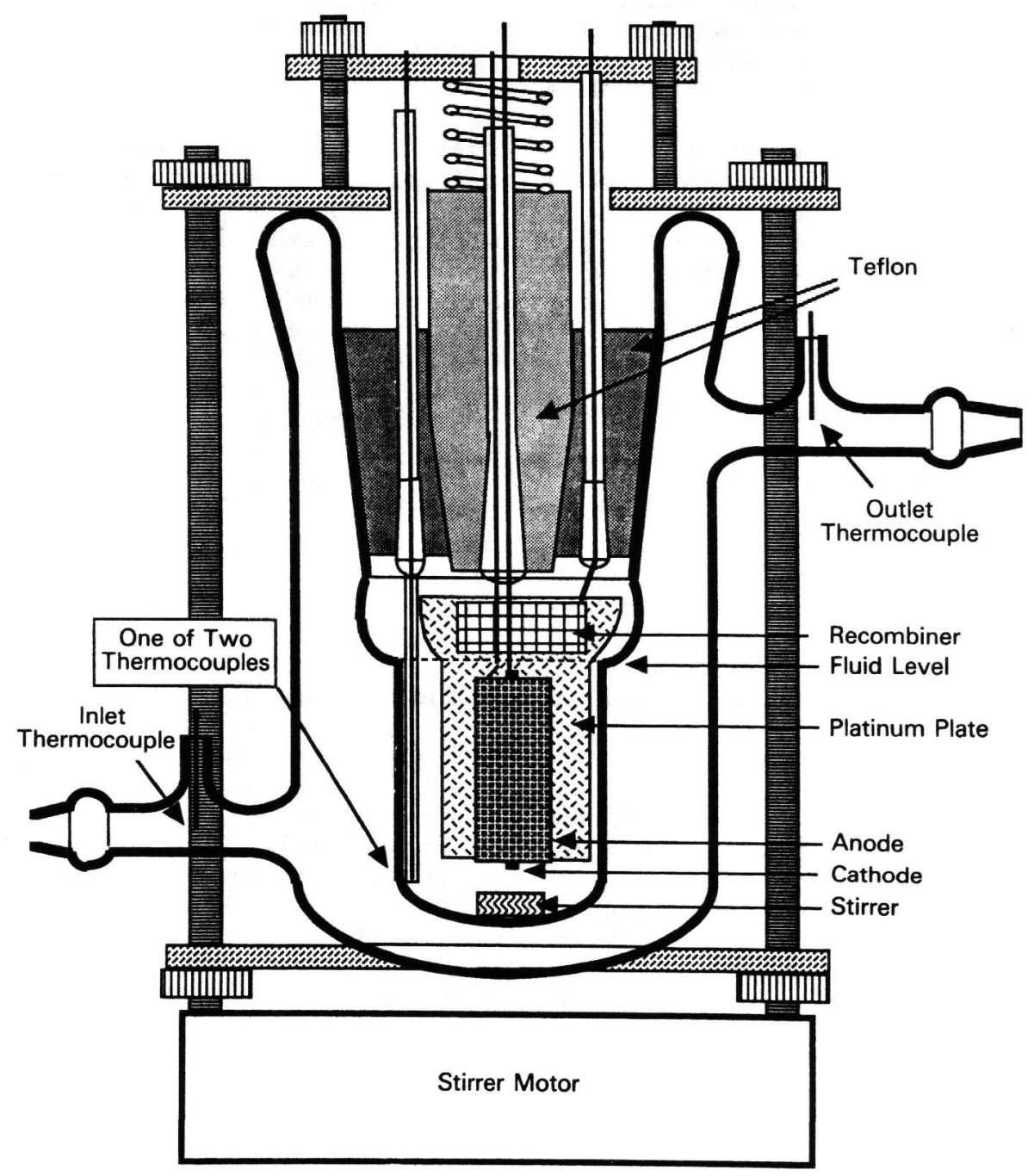

Fig. 1. Cross section of the calorimeter. 


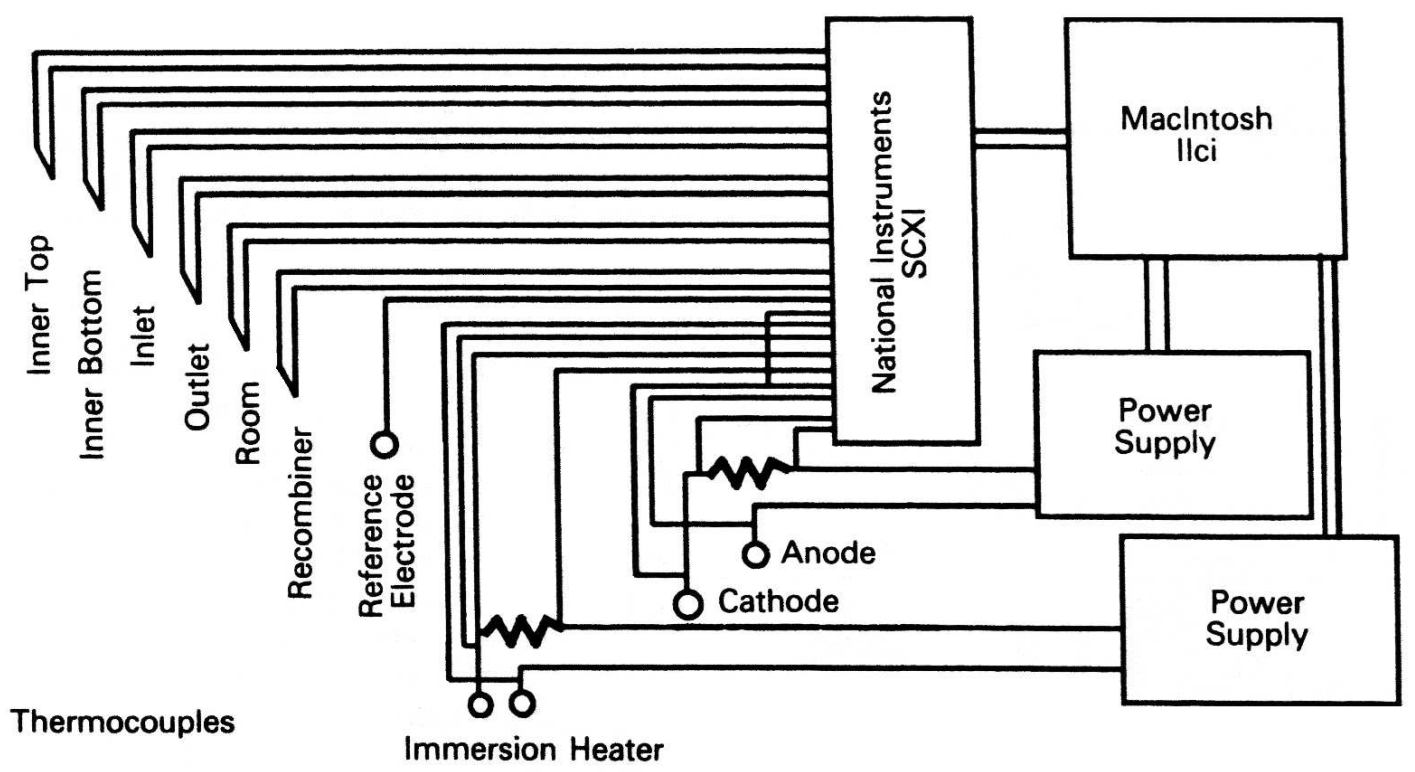

Fig. 2. Electrical connections to the data acquisition system.

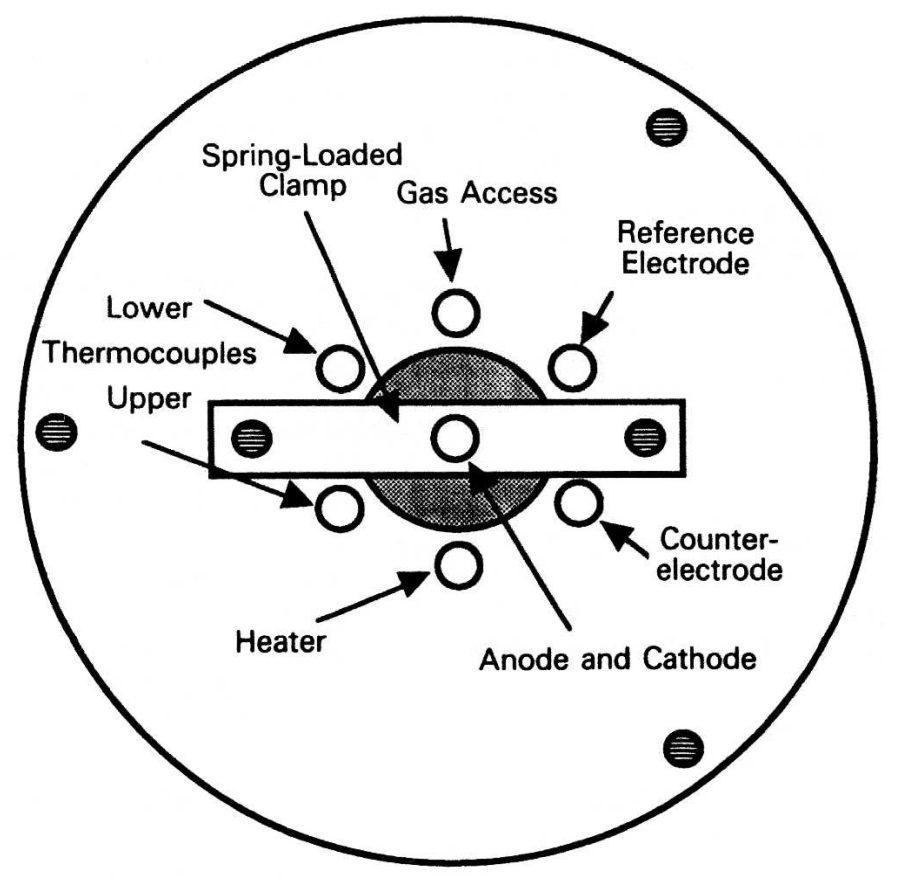

Fig. 3. Top view of probe positions. The reference electrode is an electrolyte bridge from the cathode to an exterior platinum electrode. The counter electrode is a piece of platinum immersed in the electrolyte.

\section{II.B.1. Anode-Cathode Relationship}

Uniform charging of the palladium with deuterium is generally agreed to be an essential feature for successful excess heat production. Because a plate is studied, a coplanar arrangement is used. A cross section of the anode-cathode assembly is shown in Fig. 4. The anode is platinum gauze having seventeen 0.006-in. wires per centimetre that are wrapped around Teflon posts. These posts center the cathode in the assembly with 9 -mm spacing between the anode and the 
cathode. A heavy platinum wire makes electrical contact along one edge of the anode to transmit uniform charging current to the anode.

\section{II.B.2. Electrolyte}

The electrolyte used in these studies is double-distilled $\mathrm{D}_{2} \mathrm{O}$ containing $99.76 \mathrm{~mol} \% \mathrm{D}_{2} \mathrm{O}$ and $0.3 \mathrm{MLiOD}$ (natural lithium). The liquid is stored in a plastic bottle. Because of chemical interactions of lithium with oxygen in the electrolyte and with carbon in the recombiner, the concentration of lithium in the cell solution slowly decreases as $\mathrm{Li}_{2} \mathrm{CO}_{3}$ is formed on the recombiner. In addition, the solution gradually becomes saturated with $\mathrm{CO}_{2}$.

\section{II.B.3. Temperature Measurement}

Temperature is measured by thermocouples at two levels within the inner region and at the inlet and outlet of the surrounding water jacket. The temperature difference across the cell wall is used to measure heat production. This difference is calculated by subtracting the average of the inlet and outlet jacket temperatures from the average of the inner top and inner bottom temperature readings.

All thermocouples (type $\mathrm{T}$ ) are compared with a calibrated mercury thermometer traceable to the National Institute of Standards and Technology and corrected to within $\pm 0.1^{\circ} \mathrm{C}$. However, the absolute error in an individual temperature is at least $\pm 1^{\circ} \mathrm{C}$ because of uncertainty in the temperature compensating circuit. It is important to note that this uncertainty is removed when $\Delta T$ is determined. The standard deviation from the mean of individual $\Delta T$ measurements at constant power is $\pm 0.02^{\circ} \mathrm{C}$ when zero power is applied to the cell and $\pm 0.07^{\circ} \mathrm{C}$ when $0.42 \mathrm{~A} / \mathrm{cm}^{2}$ $(2.8 \mathrm{~A})$ is applied.

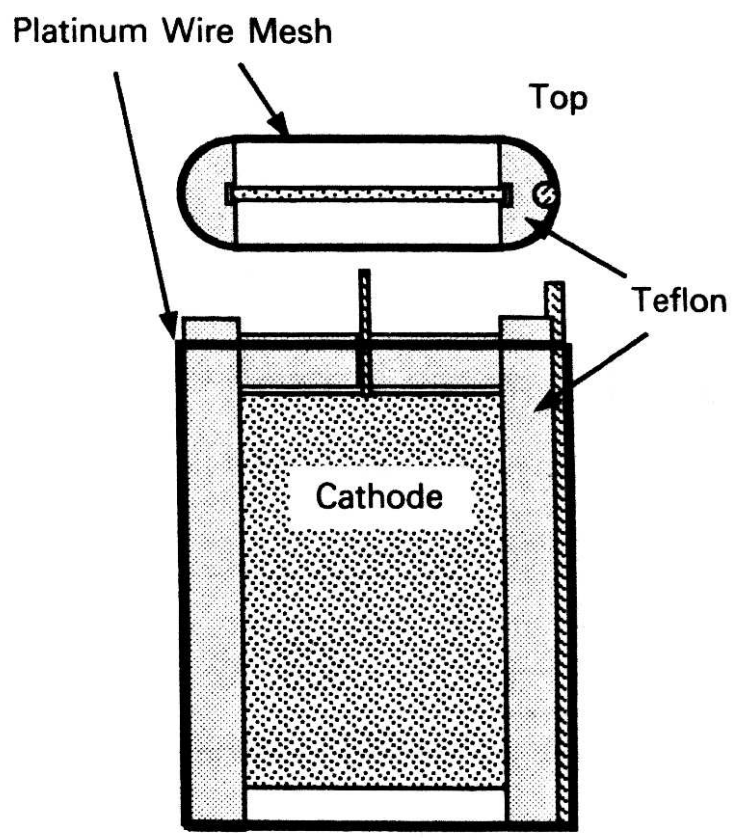

Fig. 4. View of the cathode-anode assembly. 
Room temperature and, later, the temperature of an external recombiner catalyst located in the gas handling system are also monitored. Heat generation at this location is an indication that the internal catalyst has failed to recombine all of the generated oxygen. This catalyst also prevents the unintentional buildup of an explosive mixture of $\mathrm{O}_{2}$ and $\mathrm{D}_{2}$.

\section{II.B.4. Calibration}

Calibration is done by four methods:

1. Current is passed through an internal, glass-covered immersion heater to give simple Joule heat.

2. A platinum sheet is substituted for the palladium cathode, and electrolytic heat is created using the normal anode-cathode configuration.

3. Electrolytic current is passed between the normal platinum anode and a platinum sheet that holds the recombiner.

4. The current is cycled between two values over an extended period of time using either a platinum cathode or an inactive palladium cathode. This technique is called "bivalue" in subsequent discussion.

Several of these methods contribute heat to different positions within the cell, thus testing the effect of potential temperature gradients. The time stability of the calibration is tested by the bivalue mode. A comparison between electrolytic and Joule heat tests the effect of heat being produced at the recombiner in the former case. It is important to note that method 2 has the same heat distribution, bubble pattern, and recombiner heat when palladium is studied. This method is used to calibrate the cell before and after each cell modification. Method 1 is used to detect changes in the calibration constant while palladium is being electrolyzed but is not used to provide an absolute calibration because of a small heat loss through the wires. A small charging current is applied to the palladium electrode during this calibration to prevent loss of deuterium. This additional power is taken into account. Method 4 tests the effects of the recommended bivalue mode of charging on the calibration constant. Platinum is used as the cathode, or when excess heat is not being produced, palladium is used. However, this calibration method is less accurate when palladium is used because fewer points must be taken in order not to alter the charging conditions too much.

Calibration using methods 1,2 , and 3 is accomplished by automatically sequencing the current through two cycles consisting of current steps up to a maximum then down to zero. The cell is allowed to equilibrate for $12 \mathrm{~min}$, the time needed to reach $>99 \%$ of the final value, after each current change before measurements of temperature, current, and voltage are made and recorded. A total of 72 values are normally taken to define a linear least-squares equation. These data show no curvature within the measurement range up to $50 \mathrm{~W}$. The slope of the line through the data is the calibration constant that, when multiplied by the measured $\Delta T$ across the cell wall, gives the number of watts of power $P_{T}$ being developed within the electrolyte. The constant term in the least-squares equation is caused by a small temperature offset due to slight differences in the various thermocouples. Excess power is determined by subtracting the applied power, obtained by multiplying the cell current by the applied voltage, from the measured total power $P_{T}$.

Voltage is measured at the point where the current enters the active region of the calorimeter. The voltage circuits of the Lab View data acquisition system (National Instruments SCXI and NB-MIO-16H systems for the Macintosh IIci) are calibrated to an accuracy of $\pm 0.001 \mathrm{~V}$, and the 
resistor used for current measurement is calibrated to an accuracy of $\pm 0.1 \%$. Two HP-6038A power supplies under computer control supply regulated current to the cell and the immersion heater.

Figure 5 compares calibrations made with the normal electrolytic configuration using a platinum cathode and with the immersion heater. Table II lists the values for the calibration equations and the standard deviation of the applied power (in watts) from the respective equation. The applied power is the product of the current times the voltage, and the standard deviation is obtained from the difference between the calculated watts using the calibration equation and the applied watts at each point. Although the average standard deviation is about $\pm 0.4 \mathrm{~W}$, there are variations between calibration runs that make the power uncertain by about $\pm 1 \mathrm{~W}$ at $40 \mathrm{~W}$ of applied power and $\pm 0.3 \mathrm{~W}$ near zero applied power. This results in an absolute uncertainty in the measured power of $\sim 5 \%$. On the other hand, the calorimeter is sensitive to changes in power at the $0.2 \%$ level if a sufficient number of data points are averaged.

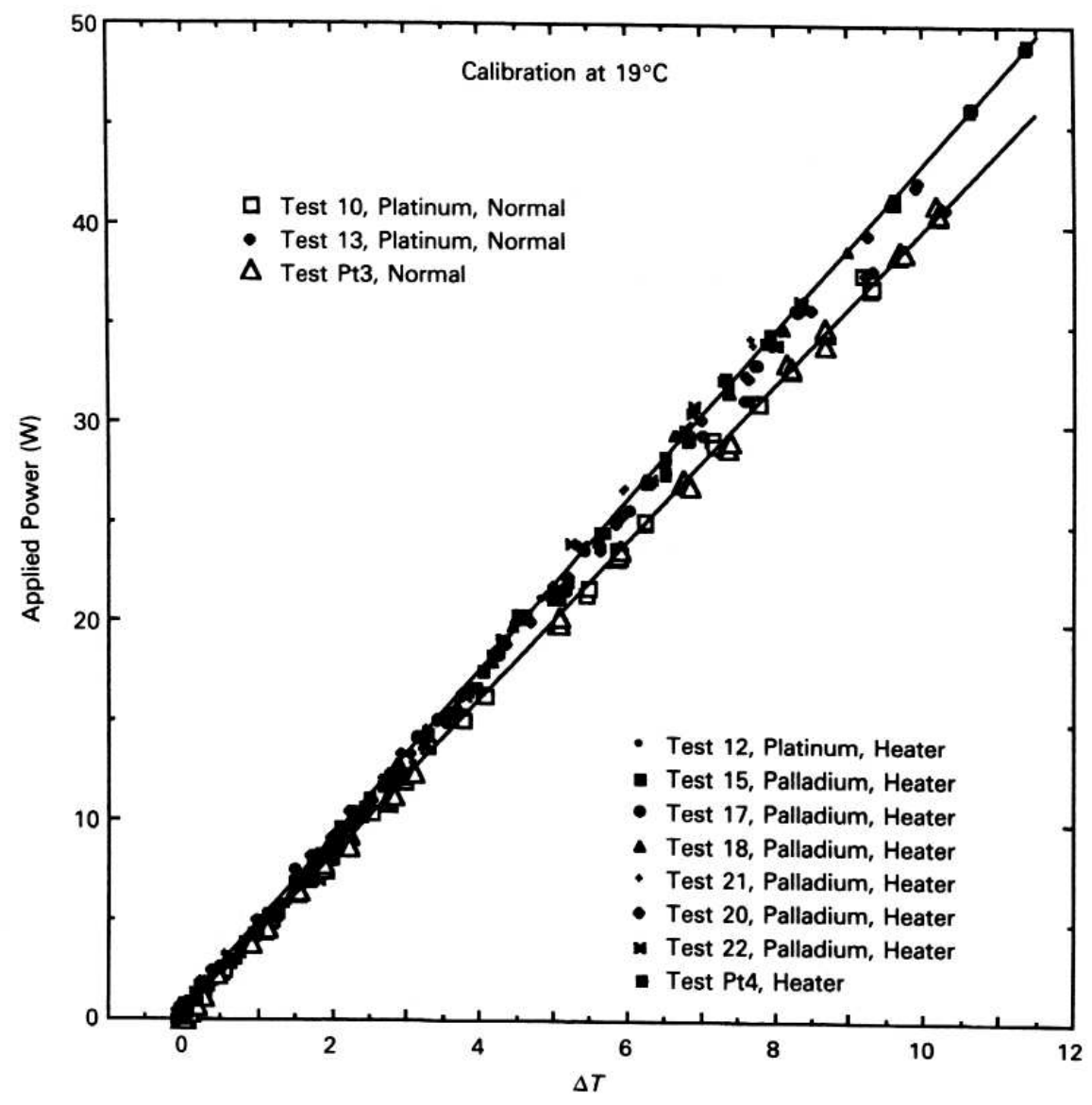

Fig. 5. Comparison between calibrations using normal electrolysis with a platinum cathode and with the immersion heater. Linear least-squares fits to the data are shown. The jacket temperature is near $19^{\circ} \mathrm{C}$, and the electrolyte is $0.3 \mathrm{~N}$ LiOD.

A slight difference between the constant obtained using the immersion heater and that using normal electrolysis is apparent. This difference is caused by a slight loss of heat from the heater through the connecting copper wires and through the air above the oil that surrounds the nichrome heater wire within the glass enclosure. 
Figure 6 compares the calibration constant obtained from individual fits with the data shown in Fig. 5, but as a function of jacket temperature. The line shown in the figure is obtained from a linear least-squares fit and results in the equation

$$
B=3.7+0.015 \mathrm{~T}_{\mathrm{J}},
$$

in which $B$ is the calibration constant and $T_{J}$ is the jacket temperature in degrees Celsius. Because most studies are made at jacket temperatures near $20^{\circ} \mathrm{C}$, an exact knowledge of the effect of jacket temperature is not necessary. An average calibration equation of

$$
\text { developed power }(\mathrm{W})=0.36+\left(3.7+0.015 T_{J}\right) \Delta T
$$

is used during the study of the first palladium sample.

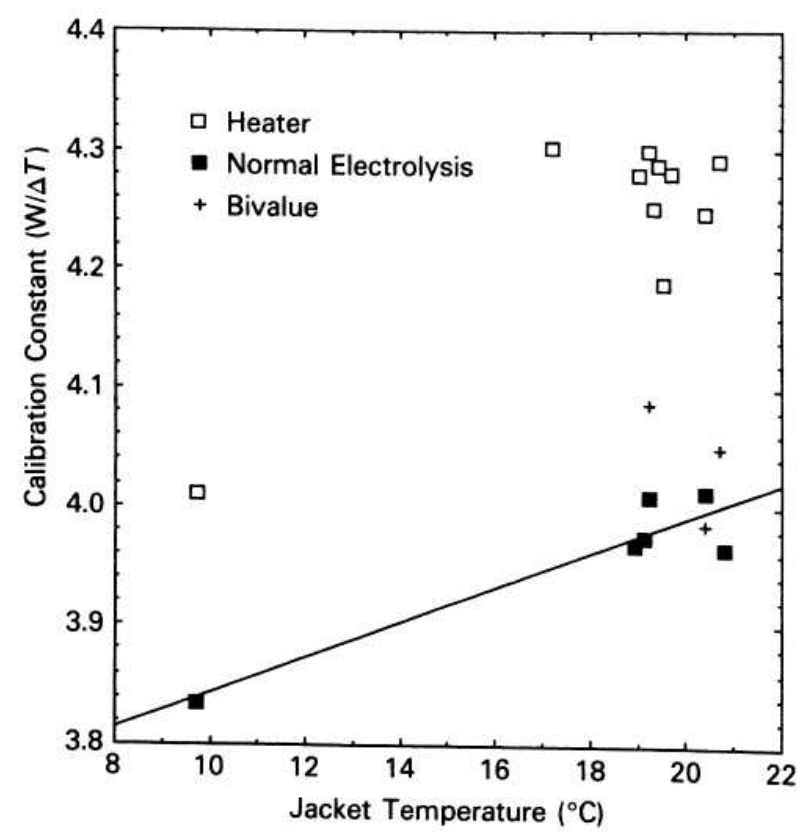

Fig. 6. Effect of jacket temperature on the calibration constant when calibration is done using the immersion heater and normal electrolysis with a platinum cathode.

\section{II.B.5. Factors Affecting Accuracy of Heat Measurement}

Because bivalue charging of the palladium cathode is used, this mode is studied by using platinum electrodes in order to determine the amount of scatter introduced. Figure 7 shows that the scatter in the apparent excess power is about $\pm 1 \mathrm{~W}$ at a current that deposits $35 \mathrm{~W}$ in the cell and $\pm 0.3 \mathrm{~W}$ at low current. This scatter is caused by local variations in the temperature within the cell as well as by rapid changes in cell voltage caused by bubble action. While a detailed statistical analysis might reveal excess heat at lower levels, the production of excess heat is not claimed unless the measured average value exceeds this scatter $( \pm 1 \mathrm{~W})$.

During excess heat production, the temperature of the electrolyte is above room temperature. Consequently, to the extent that heat could be exchanged with the room, excess heat is underestimated. 


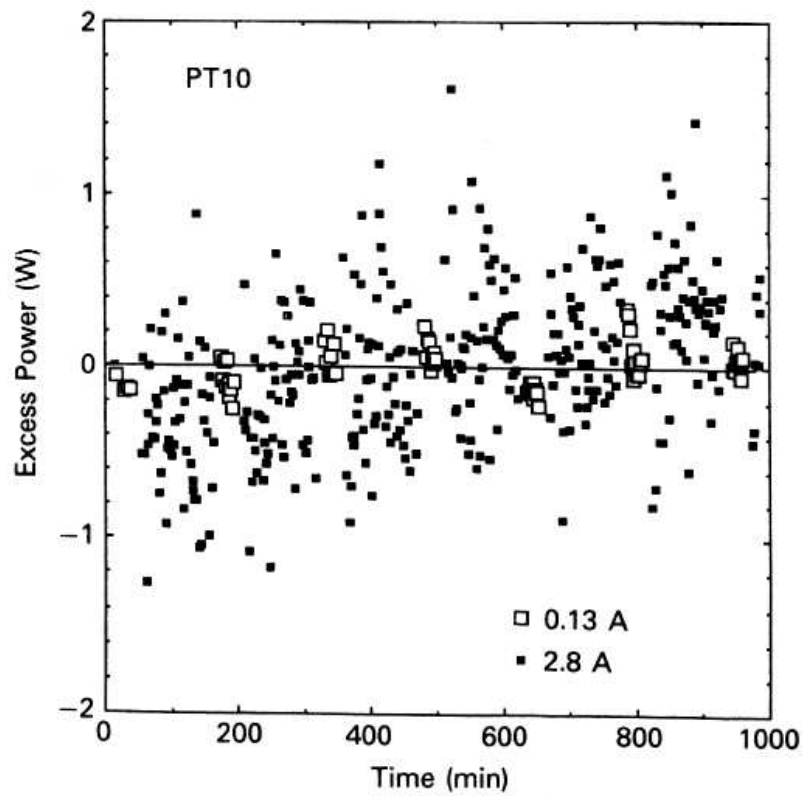

Fig. 7. Apparent excess power determined by subjecting a platinum cathode to bivalued charging at 0.13 and 2.8 A.

When apparent excess heat is observed, various tests are made to determine whether it might be an artifact of the measurement. Two artifacts are observed: (a) an abrupt 2-V negative error in the measured cell voltage when the value rises above $14 \mathrm{~V}$ and (b) a very unstable temperature reading when the cell voltage rises above $20 \mathrm{~V}$. These defects do not affect the data reported here.

Concerns have been expressed in the past about the introduction of error by temperature gradients within the cell. Although active stirring is used at all times, small gradients are observed between the top and bottom temperature probes, as can be seen in Fig. 8. The reason for this behavior can easily be understood by watching the bubble pattern during electrolysis. Stirring action pulls liquid down past the anode, up the outer wall, and past the temperature probes. Because the bottom probe sees the flowing liquid first, it becomes slightly warmer than the top probe as electrolytic power is increased. Because the cathode is less affected by this stirring action, much of its heat goes to the top of the cell. Consequently, a change in this temperature gradient at constant applied power is a sensitive indicator of a change in where heat is being produced. A tendency for the top probe to become hotter than the bottom would indicate that heat production at the cathode has increased relative to the anode. In the absence of stirring, a warmer top is observed as expected. 


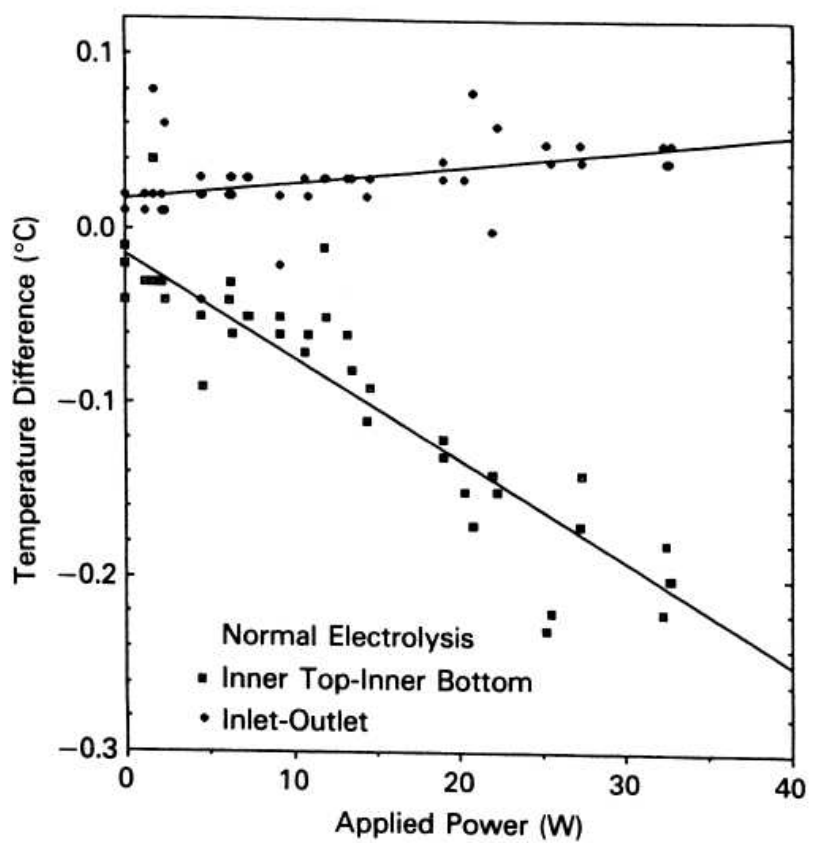

Fig. 8. Effect of applied power on the temperature difference within the electrolyte and through the flowing water in the jacket. A platinum cathode is used.

When the immersion heater is used, there is a slight gradient of $<0.1^{\circ} \mathrm{C}$ at $40 \mathrm{~W}$, and the top is hotter than the bottom. This behavior is expected because the immersion heater deposits heat uniformly with depth, while normal upward convection tends to slightly favor the top. Variations in the placement of the anode-cathode assembly change the gradient pattern without having any significant effect on the calibration constant. Consequently, these small gradients do not have an important affect on heat measurements in this calorimeter.

Flow through the jacket is so rapid that little temperature difference exists between the inlet and outlet, even at the highest power level, as shown in Fig. 8. Consequently, the fixed bath temperature is not affected by power production within the cell. However, there are abrupt fluctuations of about $\pm 0.3^{\circ} \mathrm{C}$ in the bath temperature due to limitations in the bath temperature controller. These occasional fluctuations do introduce some scatter in the $\Delta T$ measurements and appear to be the major cause of outliers.

When stirring is stopped, the top temperature tends to increase slightly $\left(<0.4^{\circ} \mathrm{C}\right)$ with respect to the bottom, and the calibration constant decreases significantly. Although bubble action alone prevents serious temperature gradients from developing, apparently the stagnant liquid barrier at the glass surface is not altered as it is when active mechanical stirring is used. Consequently, if stirring action should decrease during a run, the resulting temperature increase could be interpreted as excess heat. 
TABLE II

Comparison of Coefficients in Least-Squares Equations

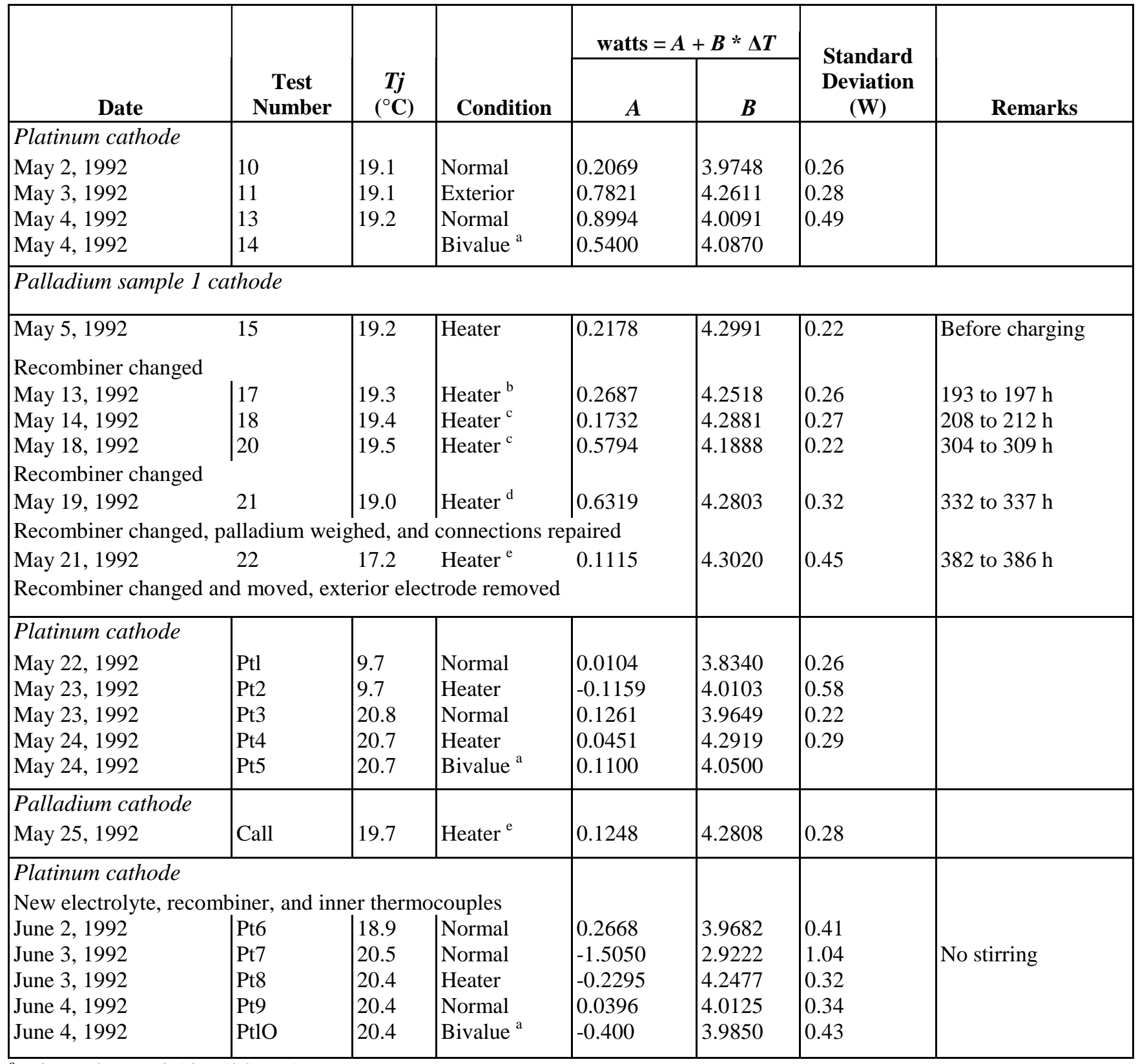

${ }^{\mathrm{a}}$ Using values at 0.13 and $2.77 \mathrm{~A}$.

b 0.25 -A electrolysis current applied along with heater power.

${ }^{\mathrm{c}} 1.0-\mathrm{A}$ electrolysis current applied along with heater power.

d 0.5 -A electrolysis current applied along with heater power.

e 0.3 -A electrolysis current applied along with heater power.

f 0.13 -A electrolysis current applied along with heater power 


\section{II.C. Additional Measurements}

The ambient deuterium pressure in the calorimeter and the cathode potential, referenced to a platinum electrode, are measured to reveal changes in the deuterium/palladium (D/Pd) ratio of the cathode bulk and surface, respectively.

\section{II.C.I. Deuterium Pressure Measurement}

A Baratron pressure transducer $( \pm 0.1 \%$ full scale, 0 to $1000 \mathrm{~mm})$ is used to measure the $\mathrm{D}_{2}$ pressure within the system. Changes in this pressure combined with the known volume of the gas system allow the amount of deuterium taken up by the palladium to be determined. This pressure is corrected for changes in room temperature. When determined in this manner, the $\mathrm{D} / \mathrm{Pd}$ ratio is accurate to \pm 0.005 during the first few days. However, there is a gradual increase in pressure over time that is proposed to be caused by interaction between oxygen and carbon in the catalyst to form $\mathrm{CO}_{2}$, thereby leaving behind excessive deuterium. Consequently, after a few days, the pressure cannot be used to obtain an absolute $\mathrm{D} / \mathrm{Pd}$ ratio, although short-term relative changes can be seen. A weight measurement at $405 \mathrm{~h}$ gives a $\mathrm{D} / \mathrm{Pd}$ ratio that agrees within \pm 0.002 with the $\mathrm{D} / \mathrm{Pd}$ ratio obtained from a pressure measurement made at $10 \mathrm{~h}$.

\section{II.C.2. Cathode Surface Potential Measurement}

A capillary probe is placed within $\sim 0.5 \mathrm{~mm}$ of the cathode surface, and the voltage between the cathode and an activated platinum sheet immersed in the electrolyte outside the cell is measured. This voltage has no absolute meaning because the reference electrode was not calibrated. On the other hand, relative changes in this voltage at constant cell current are significant and are used as an indication of changes in the surface D/Pd ratio. This voltage is also sensitive to the deposition of impurities on the surface, to the dissolution of lithium in the palladium, and to changes in electrolyte resistivity. However, these processes are relatively slow compared with changes in deuterium content, at least during initial charging.

\section{STUDY OF PALLADIUM}

\section{III.A. Initial Loading of Palladium Sample 1}

After assembly, the calorimeter is evacuated several times and backfilled with $\mathrm{D}_{2}$ gas at an initial pressure of $692 \mathrm{~mm}$. Calibration using the immersion heater is done, giving the result shown in Table II. Because there are no significant differences between this calibration and the ones done previously, all the calibrations are combined as described previously to give Eq. (2) and applied to the first part of the study. 


\section{III.B. Initial Charging of Palladium Sample 1}

Initial loading is done at a constant current of $0.13 \mathrm{~A}\left(0.02 \mathrm{~A} / \mathrm{cm}^{2}\right)$. Figure 9 compares the measured $\mathrm{D} / \mathrm{Pd}$ ratio with the ideal ratio, assuming that all deuterium atoms produced by electrolysis are dissolved in the metal. For the first $150 \mathrm{~min}$, essentially all of the deuterium dissolves. Once a ratio of 0.82 is achieved, loading is stopped. The following slight indication of deuterium loss is not thought to be meaningful. There is no subsequent indication, to the extent that uncertainties allow, that higher bulk $\mathrm{D} / \mathrm{Pd}$ ratios are achieved during subsequent treatments. A later measurement of weight change indicated a D/Pd ratio of 0.82 .

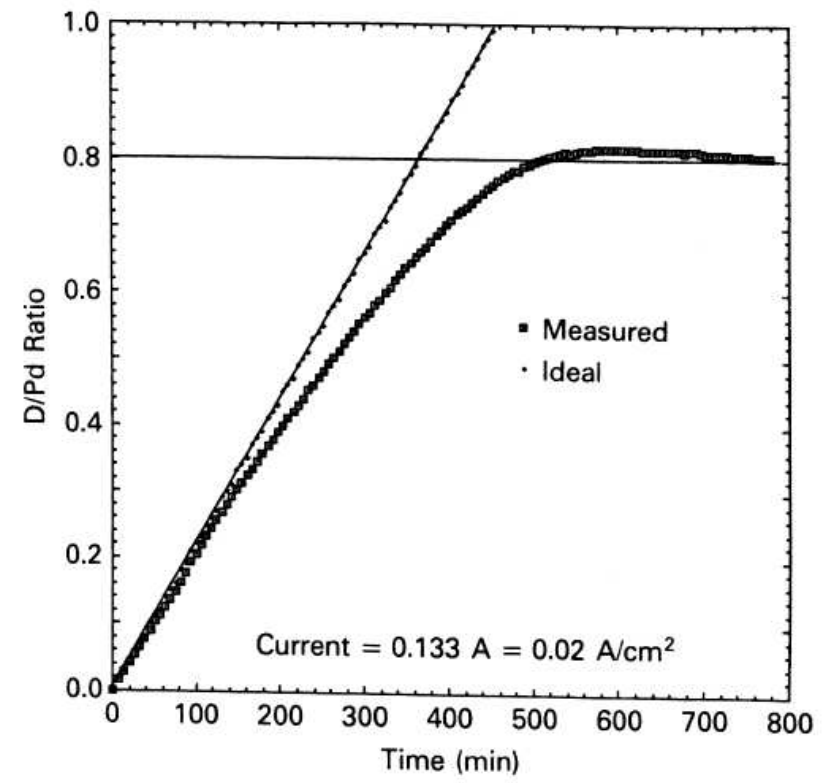

Fig. 9. The D/Pd ratio as a function of time during the initial charging of palladium sample 1.

Both the voltage at the capillary probe and the cell voltage show a similar relationship to the $\mathrm{D} / \mathrm{Pd}$ ratio during this time, as shown for the probe voltage in Fig. 10. Changes in slope correspond to previously reported compositions of the equilibrium phase boundaries at 1 atm $\mathrm{D}_{2}$ and $25^{\circ} \mathrm{C}$. This agreement with previous equilibrium measurements suggests that the composition gradient within the palladium is small at this loading current. 


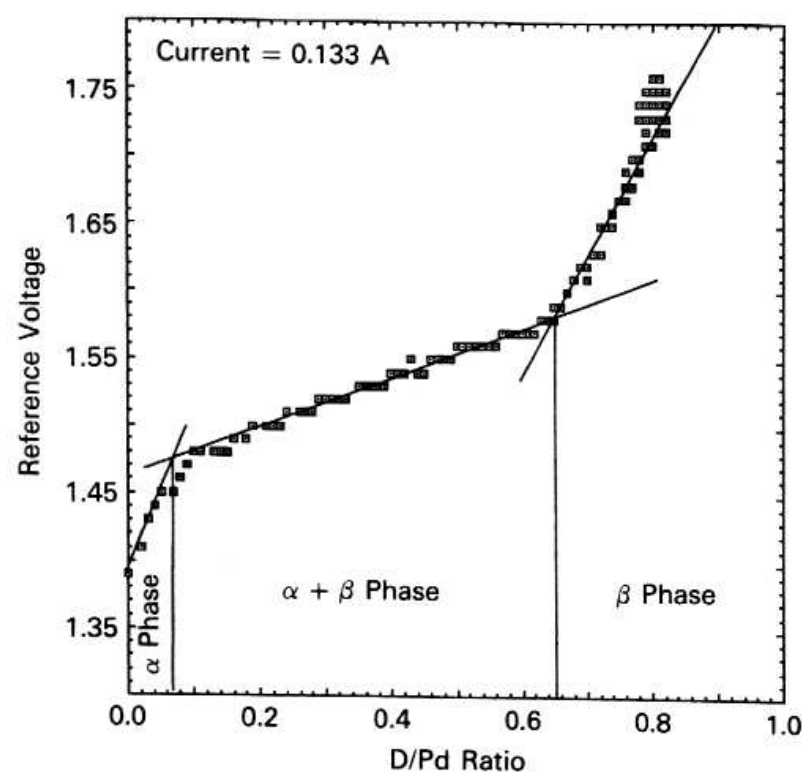

Fig. 10. Relationship between probe voltage and D/Pd ratio when charging palladium sample 1 at constant current.

During charging, the excess power is equal to zero within the uncertainty of the measurement. Table III summarizes the history of palladium sample 1 . This detail is included because the importance of charging history is not known at this time. During the first $17.2 \mathrm{~h}$, the sample is loaded at constant current. For the next $65.4 \mathrm{~h}$, the current is ramped in steps beginning at the lower current and extending to the upper current limit, then the current is abruptly returned to the lower current, as recommended by Takahashi. This cycle is repeated at the intervals noted in the table. Periodically during this treatment, the current is fixed at the lower current, and measurements of excess heat are made. There is no indication during this time that excess heat is being produced at $0.13 \mathrm{~A}$. Because the calorimeter is not in equilibrium during the ramp mode, it is not possible to know whether excess heat is being made at the other currents. This limitation is overcome by using a bivalue current mode that allows the calorimeter to stabilize before the current is again changed. 
TABLE III Charging History of Palladium Sheet 1

\begin{tabular}{|c|c|c|}
\hline Data Set & $\begin{array}{c}\text { Time } \\
\text { (h) }\end{array}$ & Treatment \\
\hline \multicolumn{3}{|l|}{ May 5, 1992} \\
\hline Test 15 & & Calibrated using heater \\
\hline $\operatorname{Pd} 1$ & 0 to 17.2 & Charged at $0.13 \mathrm{~A}$ \\
\hline \multirow[t]{3}{*}{$\operatorname{Pd} 2$} & 17.2 to 17.5 & Ramped from 0.13 to $2.77 \mathrm{~A}$ \\
\hline & 17.5 to 18.0 & Held at $0.13 \mathrm{~A}$ \\
\hline & 18.0 to 25.4 & Ramped from 0.13 to 2.77 A every $18 \mathrm{~min}$ \\
\hline \multirow[t]{2}{*}{ Pd 3} & 25.4 to 26.3 & Controlled at $0.13 \mathrm{~A}$ \\
\hline & 26.3 to 39.1 & Ramped from 0.13 to 2.77 A every 6 min \\
\hline \multirow[t]{2}{*}{$\operatorname{Pd} 4$} & 39.1 to 39.8 & Controlled at $0.13 \mathrm{~A}$ \\
\hline & 39.8 to 47.2 & Ramped from 0.13 to 2.77 A over 6 min \\
\hline \multirow[t]{2}{*}{$\operatorname{Pd} 5$} & 47.2 to 48.7 & Controlled at $0.13 \mathrm{~A}$ \\
\hline & 48.7 to 64.3 & Ramped from 0.13 to 2.77 A over 6 min \\
\hline \multirow[t]{2}{*}{$\operatorname{Pd} 6$} & 64.3 to 65.4 & Controlled at $0.13 \mathrm{~A}$ \\
\hline & 65.4 to 90.1 & Cycled between 0.13 and $2.77 \mathrm{~A}$ each 20 min \\
\hline $\operatorname{Pd} 7$ & 90.1 to 98.1 & Cycled between 0.13 and $2.77 \mathrm{~A}$ each $30 \mathrm{~min}$ \\
\hline $\operatorname{Pd} 8$ & 98.1 to 114 & Cycled and held at $0.13 \mathrm{~A}$ for $30 \mathrm{~min}$ and $2.77 \mathrm{~A}$ for $60 \mathrm{~min}$ \\
\hline Pd 9 & 114 to 122 & Cycled and held at $0.13 \mathrm{~A}$ for $30 \mathrm{~min}$ and $2.00 \mathrm{~A}$ for $60 \mathrm{~min}$ \\
\hline Pd 10 & 122 to 136 & Cycled and held at $0.13 \mathrm{~A}$ for $30 \mathrm{~min}$ and $2.50 \mathrm{~A}$ for $60 \mathrm{~min}$ \\
\hline Pd 11 & 136 to 146 & Cycled and held at $0.13 \mathrm{~A}$ for $30 \mathrm{~min}$ and $2.80 \mathrm{~A}$ for $60 \mathrm{~min}$ \\
\hline \multirow[t]{2}{*}{$\mathrm{Pd} 12$} & 146 to 159 & Cycled and held at $0.13 \mathrm{~A}$ for $30 \mathrm{~min}$ and $0.5 \mathrm{~A}$ for $60 \mathrm{~min} ; 6 \mathrm{ml} \mathrm{D}_{2} \mathrm{O}$ added \\
\hline & 159 to 160 & Cell turned off and recombiner replaced; cathode in air for most of the time ( $47 \mathrm{~min})$ \\
\hline \multirow[t]{2}{*}{$\operatorname{Pd} 13$} & 160 to 170 & Controlled at $0.13 \mathrm{~A}$ \\
\hline & 170 to 186 & Controlled at $0.25 \mathrm{~A}$; recombiner thermocouple installed \\
\hline Test 17 & 186 to 208 & Calibrated while electrolyzing at $0.25 \mathrm{~A}$ using heater \\
\hline \multirow[t]{2}{*}{ Test 18} & 208 to 216 & Calibrated while electrolyzing at $1.0 \mathrm{~A}$ using heater \\
\hline & 216 to 232 & Controlled at $0.25 \mathrm{~A}$ \\
\hline \multirow[t]{2}{*}{$\operatorname{Pd} 14$} & 232 to 238 & Cycled and held at $0.25 \mathrm{~A}$ for $30 \mathrm{~min}$ and $2.8 \mathrm{~A}$ for $60 \mathrm{~min}$ \\
\hline & 238 to 258 & Cycled and held at $0.40 \mathrm{~A}$ for $30 \mathrm{~min}$ and $2.8 \mathrm{~A}$ for $180 \mathrm{~min}$ \\
\hline $\operatorname{Pd} 15$ & 258 to 267 & Cycled and held at $1.0 \mathrm{~A}$ for $30 \mathrm{~min}$ and $2.8 \mathrm{~A}$ for $180 \mathrm{~min}$ \\
\hline \multirow[t]{2}{*}{ Pd 16} & 267 to 270 & Controlled at $2.0 \mathrm{~A}$ \\
\hline & 270 to 289 & Cycled and held at $1.0 \mathrm{~A}$ for $30 \mathrm{~min}$ and $2.8 \mathrm{~A}$ for $180 \mathrm{~min}$ \\
\hline $\operatorname{Pd} 17$ & 289 to 304 & Controlled at $2.8 \mathrm{~A}$ \\
\hline Test 20 & 304 to 312 & Calibrated while electrolyzing at $1.0 \mathrm{~A}$ using heater \\
\hline \multirow[t]{2}{*}{$\mathrm{Pd} 18$} & 312 to 331 & Cycled and held at $0.5 \mathrm{~A}$ for $30 \mathrm{~min}$ and $2.8 \mathrm{~A}$ for $180 \mathrm{~min}$ \\
\hline & 331 to 332 & Recombiner replaced; $6 \mathrm{ml} \mathrm{D} 2 \mathrm{O}$ added $+1.0 \mathrm{ml}$ electrolyte; cathode in air \\
\hline Test 21 & 332 to 337 & $\begin{array}{l}\text { Calibrated while electrolyzing at } 0.5 \text { A using heater; cell resistance dropped from } 7.5 \\
\text { to } 3 \Omega \text {; no bubbles }\end{array}$ \\
\hline \multirow[t]{2}{*}{$\operatorname{Pd} 19 \& 20$} & 337 to 381 & Controlled at $20 \mathrm{~V},=0.7 \mathrm{~A}$; poor electrical contact in cell \\
\hline & 381 to 382 & $\begin{array}{l}\text { Cell opened and connection repaired; palladium washed with acetone, weighed, and } \\
\text { placed in liquid nitrogen; } 2 \text { ml electrolyte added; new recombiner }\end{array}$ \\
\hline Test 22 & 382 to 387 & Calibrated while electrolyzing at $0.3 \mathrm{~A}$ using heater \\
\hline \multirow[t]{2}{*}{$\operatorname{Pd} 21$} & 387 to 401 & $\begin{array}{l}\text { Cycled and held at } 0.3 \mathrm{~A} \text { for } 30 \mathrm{~min} \text { and } 2.8 \mathrm{~A} \text { for } 180 \mathrm{~min} \text {; bath controller failed; } \\
T=5^{\circ} \mathrm{C}\end{array}$ \\
\hline & $\begin{array}{r}401 \text { to } 405 \\
405\end{array}$ & $\begin{array}{l}\text { Electrical connection to anode broke; no bubbles; palladium washed with acetone, } \\
\text { weighed, and placed in liquid nitrogen }\end{array}$ \\
\hline
\end{tabular}


TABLE III (Continued)

\begin{tabular}{|c|c|c|}
\hline Data Set & $\begin{array}{c}\text { Time } \\
\text { (h) }\end{array}$ & Treatment \\
\hline \multicolumn{3}{|c|}{ May 22, 1992} \\
\hline \multicolumn{3}{|c|}{ The following changes were made in the cell: } \\
\hline \multicolumn{3}{|c|}{$\begin{array}{l}\text { 1. The exterior electrode was removed, and its electrical connector was attached to the anode. This caused the } \\
\text { anode-cathode structure to be moved off center. } \\
\text { 2. The recombiner was placed on a platinum screen at the top of the gas space. }\end{array}$} \\
\hline \multicolumn{3}{|c|}{ 3. The electrolyte was replaced. } \\
\hline \multicolumn{3}{|c|}{ 4. A platinum cathode was installed. } \\
\hline Pt1 & & Calibration using normal electrolysis \\
\hline Pt2 & & Calibration using internal heater \\
\hline Pt3 & & Calibration using normal electrolysis \\
\hline Pt4 & & Calibration using internal heater \\
\hline Pt5 & & Cycled and held at $0.13 \mathrm{~A}$ for $30 \mathrm{~min}$ and $2.8 \mathrm{~A}$ for $180 \mathrm{~min}$ \\
\hline \multicolumn{3}{|c|}{ May 25, 1992} \\
\hline \multicolumn{3}{|c|}{ The palladium cathode was returned to cell, and the electrolyte was replaced. } \\
\hline Cal1 & 477 to 482 & Calibrated using internal heater +0.13 -A electrolysis \\
\hline $\operatorname{Pd} 22$ & 482 to 505 & $\begin{array}{l}\text { Held at } 0.13 \mathrm{~A} \\
\text { Cycled and held at } 0.5 \mathrm{~A} \text { for } 30 \mathrm{~min} \text { and } 2.8 \mathrm{~A} \text { for } 180 \mathrm{~min}\end{array}$ \\
\hline $\operatorname{Pd} 23$ & 505 to 522 & Fixed at $2.8 \mathrm{~A}$ \\
\hline $\mathrm{Pd} 24$ & 522 to 543 & Cycled and held at $1.0 \mathrm{~A}$ for $30 \mathrm{~min}$ and $2.8 \mathrm{~A}$ for $180 \mathrm{~min}$ \\
\hline
\end{tabular}

\section{III.C. Excess Heat Production}

A bivalue mode is used starting at $65.4 \mathrm{~h}$ with the times and upper current values listed in Table III. Once this mode is adopted, excess energy is observed, as shown in Fig. 11. An indication of excess power is first observed after $90 \mathrm{~h}$, and |his fluctuates between 0 and $2 \mathrm{~W}$ at 2.8 and 2.5 A throughout the study. No excess is observed at 2.0, 0.5, and $0.13 \mathrm{~A}$.

Unfortunately, the cell is observed to lose fluid, and water begins to appear in the gas system at the external recombiner. Thus, at some time during this study, but after calibration, the recombiner within the cell has stopped recombining most of the released oxygen. The exact time is unknown because the temperature of the external recombiner was not yet being recorded. Consequently, the excess heat values are lower limits to the actual heat produced. The remaining energy leaves the cell as oxygen.

At $159 \mathrm{~h}$, the cell is opened, and the recombiner is replaced. This operation requires that the cathode be exposed to air for $\sim 47$ min with a resulting slight loss of deuterium. After reassembly, the cell is calibrated, and the bivalue mode is resumed. The resulting excess heat is plotted in Fig. 12. After $\sim 5 \mathrm{~h}$, a small burst of heat is observed, followed by a steady increase over the next $55 \mathrm{~h}$. A calibration using the immersion heater is run between 304 and $312 \mathrm{~h}$ while $1.0 \mathrm{~A}$ of 
current is applied to the cathode. Periodically, excess power measurements are made at various lower currents. Not only is the excess absent at 2.0 A and below, but these periodic interruptions do not seem to alter the steady rise once $2.8 \mathrm{~A}$ is resumed. At $295 \mathrm{~h}$, the recombiner begins to fail again, and the measured excess power begins to decrease. This failure can be seen in the temperature rise at the external recombiner shown in Fig. 13. If no oxygen were being recombined in the cell at $330 \mathrm{~h}, 4.3 \mathrm{~W}(2.8 \mathrm{~A} \times 1.54 \mathrm{~V})$ would have to be added to the measured excess to give the actual value. When this is done, the value falls on the upward trend created by the earlier data. Thus, the upward trend in power generation apparently continues to the point when the cell is again turned off.

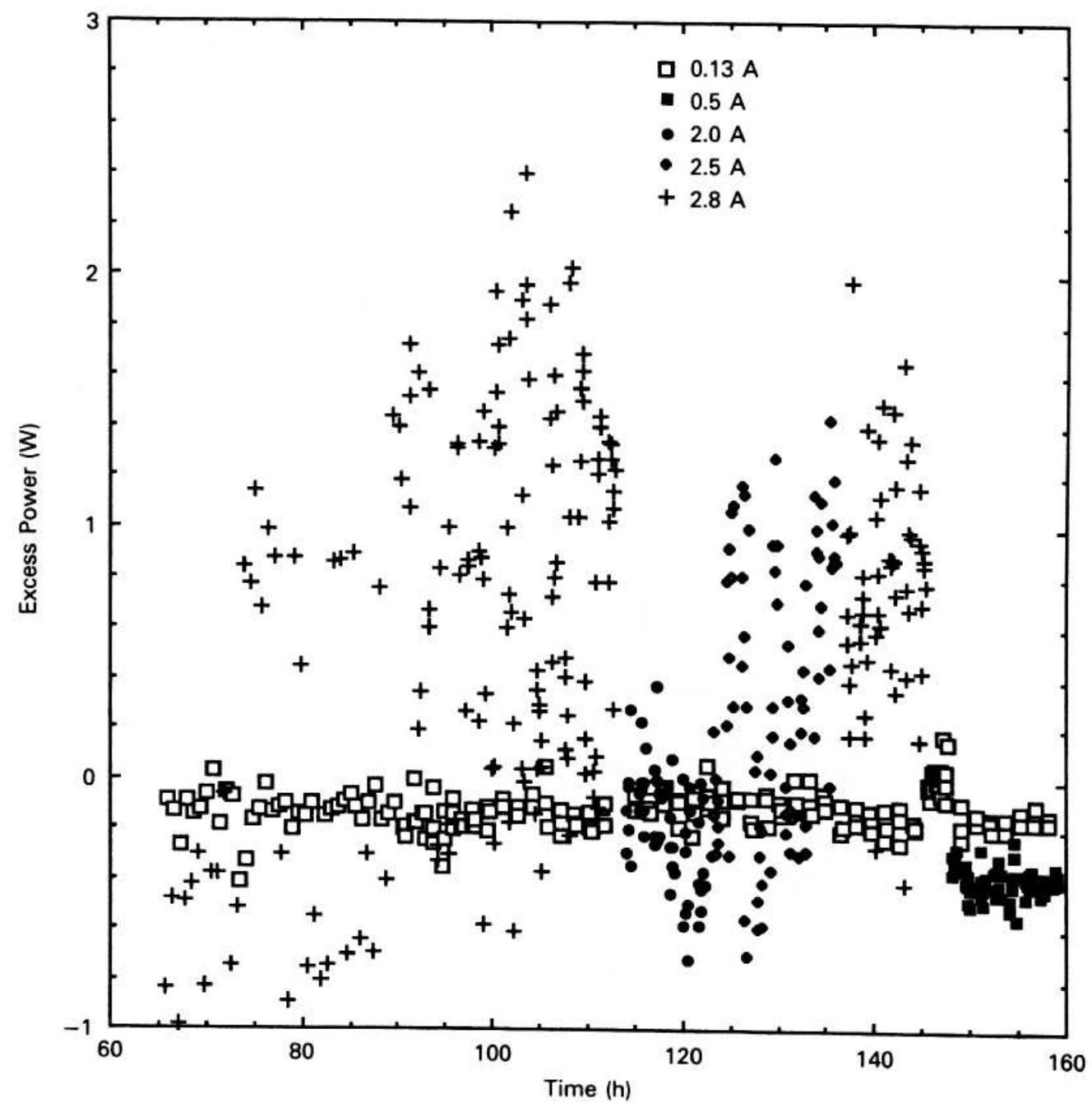

Fig. 11. Excess power for the high- and low-current modes as a function of time during phase 1 . The current values are indicated. 


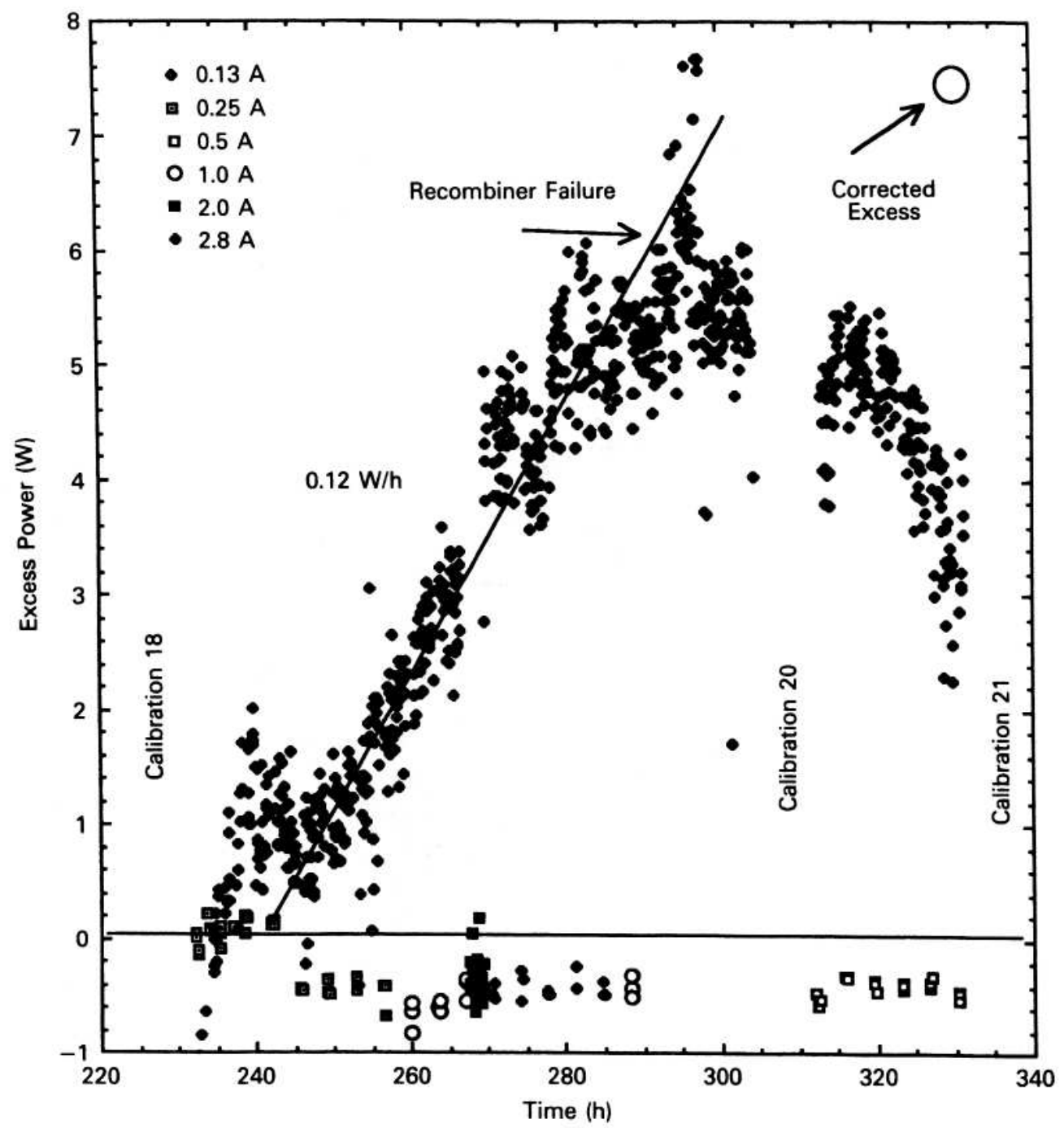

Fig. 12. Excess power at various cell currents during phase 2. The "corrected excess" value is the maximum excess power expected if the recombiner had worked properly. 


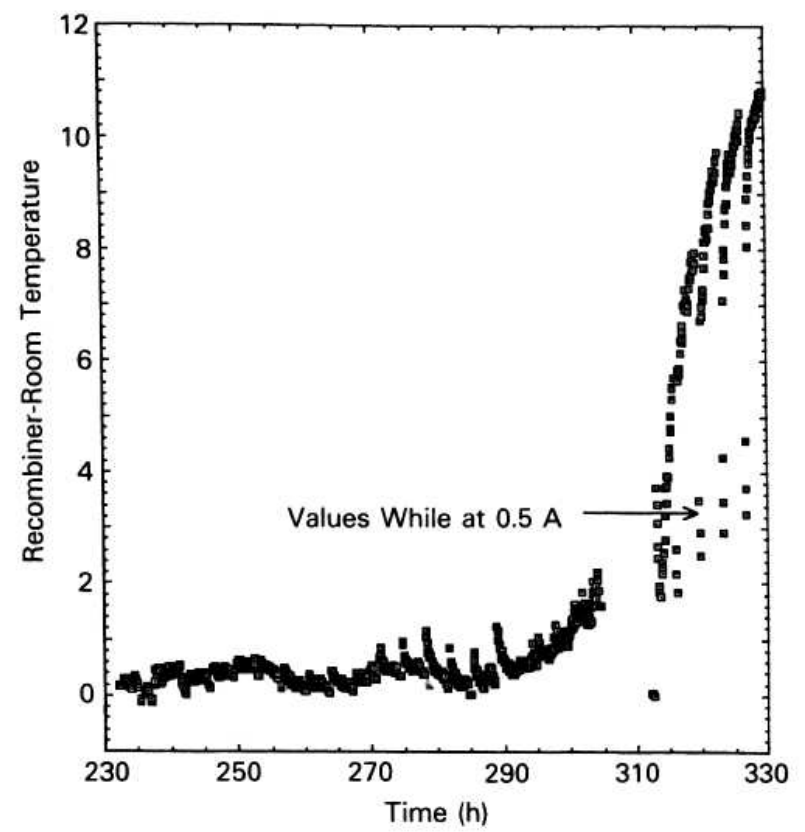

Fig. 13. Temperature difference between the external recombiner and room temperature as a function of time.

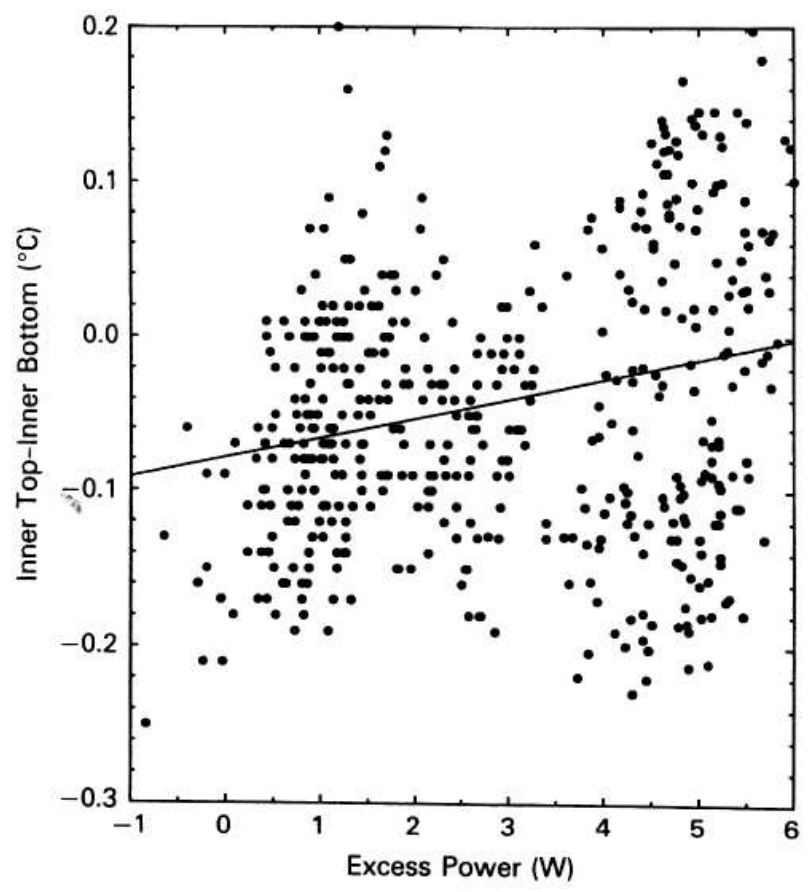

Fig. 14. Relationship between excess power and inner temperature gradient when $2.8 \mathrm{~A}(38.4 \mathrm{~W})$ is applied. The line is a linear least-squares fit to the data.

While excess power is being produced, the normal temperature gradient in the cell changes. Although the effect shown in Fig. 14 is rather scattered, the least-squares line suggests a trend toward an increase in the top temperature relative to the bottom as excess power increased. This 
trend is opposite to that found when electrolytic power is increased without the production of excess power, as shown by Figs. 15 and 8. Figure 15 shows the effect of applied power at currents below those producing excess power during this phase, while Fig. 8 shows the effect when platinum was used as the cathode. This difference suggests that the excess heat is originating from a different position in the cell than does electrolytic heat. This position is proposed to be the palladium cathode, a region that deposits its heat mainly at the top of the cell.

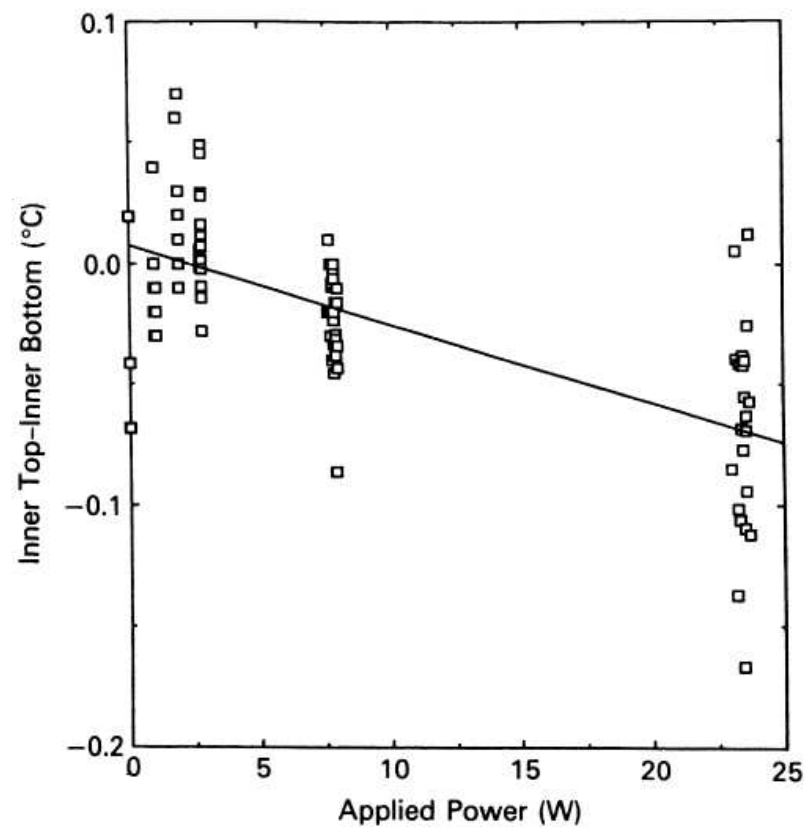

Fig. 15. Effect of applied power on the inner top and bottom temperature at power levels below where excess power is observed during phase 2.

At $331 \mathrm{~h}$, the cell is shut down again for $78 \mathrm{~min}$ to replace the recombiner. When the current is again turned on, a poor electrical connection is found within the cell. The cell is again opened, and the palladium is washed with acetone, weighed, and placed in liquid nitrogen. The D/Pd ratio is 0.818 based on the weight. At $382 \mathrm{~h}$, the cell is assembled and calibrated using the immersion heater while electrolyzing at $0.3 \mathrm{~A}$. A small excess power production resumes when the current is raised to $2.8 \mathrm{~A}$, as shown in Fig. 16. 


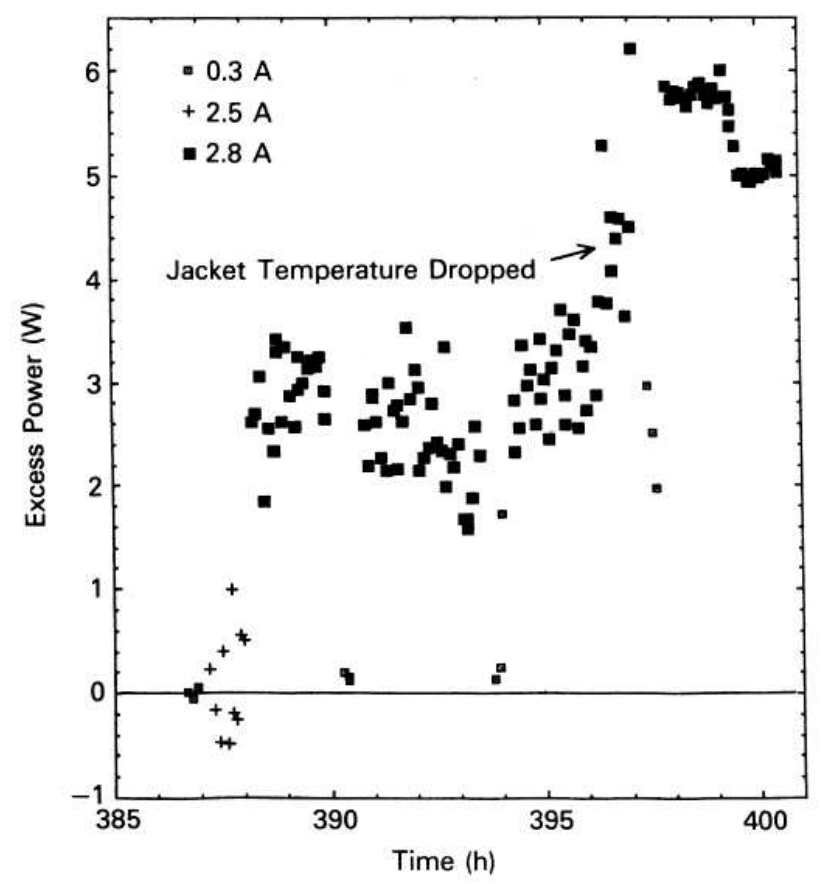

Fig. 16. Excess heat production during phase 3.

At $397 \mathrm{~h}$, a sharp drop in room temperature causes failure of the bath temperature controller. The jacket temperature drops to $\approx 5^{\circ} \mathrm{C}$, and any quantitative measure of excess heat is lost. At 401 $\mathrm{h}$, electrical connection to the cathode breaks, and the metal is without charging current for $4 \mathrm{~h}$. The D/Pd ratio drops to 0.73 based on the weight. The metal is placed in liquid nitrogen while repairs are made, calibrations are done, and palladium sample 2 is studied. Before palladium sample 1 is returned to the calorimeter, the lower halves of both sides are sanded with 600-grit $\mathrm{SiC}$ paper until bright. This material is studied for $314 \mathrm{~h}$ at various currents up to $3.5 \mathrm{~A}$ and at temperatures between 10 and $30^{\circ} \mathrm{C}$. At the end of the study, the $\mathrm{D} / \mathrm{Pd}$ ratio is 0.64 , and most of the out-gassing is occurring from the region that had been sanded. These efforts fail to show further excess heat production.

\section{III.D. Excess Volume Measurement}

When palladium loads with hydrogen, stresses that develop when the $\alpha$ phase converts to the $\beta$ phase can introduce cracks and dislocations and cause excess volume. This excess volume reduces the ability of palladium to achieve an average, high D/Pd ratio. ${ }^{29}$ A comparison between the physical volume measured before reacting with deuterium and a similar measurement when the $\mathrm{D} / \mathrm{Pd}$ ratio is equal to 0.73 shows that the material is within $0.8 \%$ of the expected volume. The excess volume increases to $1.7 \%$ at $\mathrm{D} / \mathrm{Pd}=0.64$ after the second part of the study using this palladium.

\section{III.E. Initial Loading and Study of Palladium Sample 2}

Initial loading is done at $0.020 \mathrm{~A} / \mathrm{cm}^{2}$. A small gas leak in the system, although corrected for, makes a measurement of the absolute $\mathrm{D} / \mathrm{Pd}$ ratio somewhat uncertain. This problem has a less important effect on the shape of the loading curve. As can be seen in Fig. 17, the shape of the 
loading behavior is very different from that in palladium sample 1 (Fig. 9). This palladium was treated to charging conditions similar to those used for palladium sample 1 . When no excess heat is observed during $76 \mathrm{~h}$, the cell is opened, and the palladium is weighed. The D/Pd ratio, based on the weight, is 0.75 .

A volume measurement shows that the palladium is $13.5 \%$ larger than expected based on the deuterium content.

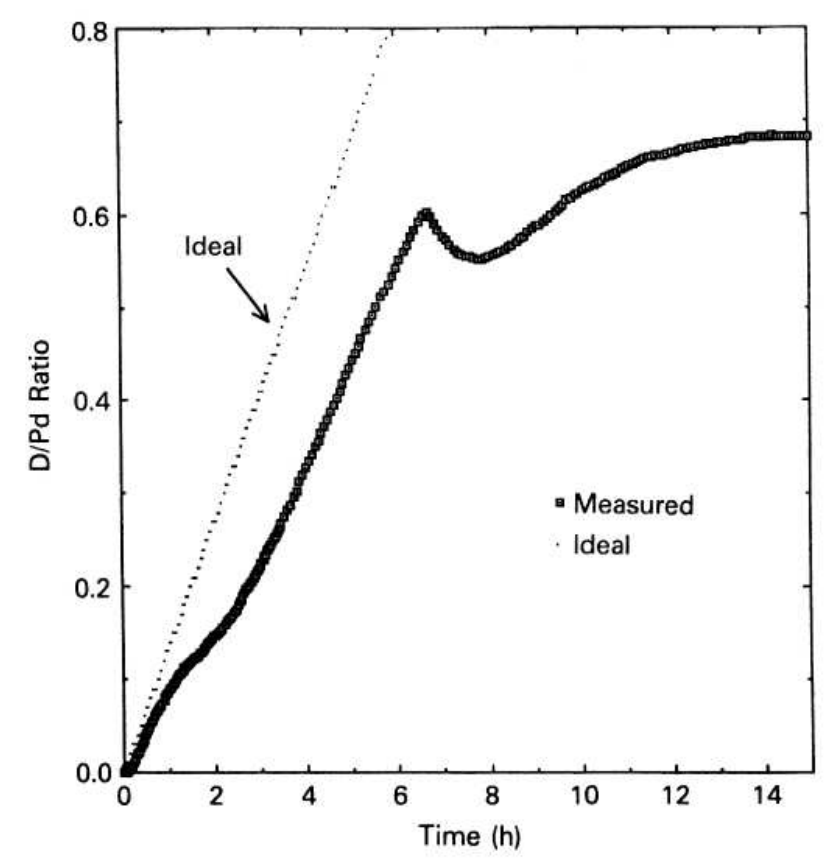

Fig. 17. Charging behavior of palladium sample 2. The ideal curve shows the expected $\mathrm{D} / \mathrm{Pd}$ ratio if all deuterium produced by electrolysis were dissolved in the palladium.

\section{CONCLUSION}

Two pieces of palladium sheet from different batches were studied. One produced excess power for a while, and the other did not.

Excess power has been produced in an electrolytic cell using palladium similar to that used by Takahashi. During the first $330 \mathrm{~h}$ of the study, excess power levels that reached $\approx 20 \%$ of applied power $(\approx 7.5 \mathrm{~W})$ were measured before the study had to be interrupted. This power increased with time while the palladium was electrolyzed at $0.42 \mathrm{~A} / \mathrm{cm}^{2}$. No measurable excess power was seen below $0.38 \mathrm{~A} / \mathrm{cm}^{2}$. This excess is $\sim 75 \%$ of the amount expected at $0.42 \mathrm{~A} / \mathrm{cm}^{2}$ as proposed by Storms ${ }^{30}$ based on a variety of calorimetric measurements.

The excess heat originated from a different position within the cell than did electrolytic heat. This position is proposed to be the palladium cathode. The palladium produced heat in spite of being exposed to air after loading with deuterium and being placed in liquid nitrogen for a short time and despite the electrolyte being saturated with $\mathrm{CO}_{2}$. However, no excess was produced after deloading to $\mathrm{D} / \mathrm{Pd}=0.73$. The bivalue mode of charging, as used by Takahashi, does not appear to be a requirement for continued heat production once production starts. 
The palladium sheet that produced excess heat was loaded to $\mathrm{D} / \mathrm{Pd}=0.82$, and the deuteride contained no significant excess volume. On the other hand, the palladium sheet that failed to show excess power was loaded to only $\mathrm{D} / \mathrm{Pd}=0.75$ and had $13.5 \%$ excess volume. One explanation is that the second piece of palladium contained internal defects that caused the formation of cracks during loading with the result that a high D/Pd ratio could not be achieved. On the other hand, sanding of the first palladium sheet prevented high loading even though no significant excess volume was created.

It is generally agreed that the production of excess energy requires high local concentrations of deuterium. To achieve high concentrations, a high rate of deuterium dissolution at the surface must occur as well as a low rate of loss from the interior through escape paths. The ability to dissolve deuterium rapidly at the surface depends in part on using a high applied current, having the absence of certain impurities but the presence of others, and having a uniform current density. No matter how fast the deuterium is loaded into the palladium, if the deuterium can escape more rapidly from the interior, a high stoichiometry cannot be achieved. Escape paths form when defects or cracks are present in the metal or when the metal is cycled between the $\alpha$ and $\beta$ phases. A routine measurement of the palladium volume during a study would help give a partial understanding of why some materials work and others do not.

Once electrolysis is started, a concentration gradient with respect to deuterium forms within the cathode. The magnitude of this gradient is determined by the relative competition among deuterium uptake, deuterium loss, and the diffusion constant. The diffusion constant is influenced by temperature and the dissolution of impurities such as lithium. The lower the temperature is, the smaller the diffusion constant and the steeper the gradient are. In any case, the highest concentration of deuterium must exist at the surface. Therefore, to the extent that the deuterium concentration is important, the heat-producing reaction will be localized at the surface. A greater fraction of the volume might become involved as electrolysis continues to raise more of the gradient above the critical composition, but this will be a slow process. Consequently, reporting heat production on the basis of the cathode volume not only conflicts with this expected behavior but also gives the false impression of a much higher heat-producing rate than was actually observed when the usual small samples were used. Based on the thin film studies by Bush and Eagleton, ${ }^{26}$ the reaction is within $5 \mu \mathrm{m}$ of the surface, and the power densities are much higher than those reported using the total cathode volume.

Changes in heat production produced by changes in current cannot be attributed to the current change alone. When the current is changed, the applied power changes, and this causes the temperature of the cathode to change. In the calorimeter used here, a change in current from 0.02 to $0.4 \mathrm{~A} / \mathrm{cm}^{2}$ causes the temperature of the electrolyte to change by $10^{\circ} \mathrm{C}$. While this does not appear to be a large amount, changes in the diffusion constant for deuterium or changes in the other processes that affect the chemical environment may be significant.

\section{ACKNOWLEDGMENTS}

The author wishes to thank D. Harbur and W. Stark for their open-minded support of this work, R. Logsdon for making the glass parts of the calorimeter, and R. Bush and R. Eagleton (California State Polytechnic University) for sharing their experience using a calorimeter of similar design. 


\section{REFERENCES}

1. A. TAKAHASHI, T. IIDA, T. TAKEUCHI, and A. MEGA, "Excess Heat and Nuclear Products by $\mathrm{D}_{2} \mathrm{O}$ Electrolysis and Multibody Fusion,” submitted to Appl. Electromag. Mater. (1992).

2. M. FLEISCHMANN and S. PONS, "Electrochemically Induced Nuclear Fusion of Deuterium," J. Electroanal. Chem., 261, 301 (1989); see also M. FLEISCHMANN and S. PONS, Errata, J. Electroanal. Chem., 263, 187 (1989); see also S. PONS and M. FLEISCHMANN, "Calorimetric Measurements of the Palladium/Deuterium System: Fact and Fiction,” Fusion Technol., 17, 669 (1990); see also S. PONS and M. FLEISCHMANN, "Calorimetry of Palladium-Deuterium Systems," Proc. 1st Annual Conf. Cold Fusion, Salt Lake City, Utah, March 28-31, 1990, p. 1, National Cold Fusion Institute (1990); see also M. FLEISCHMANN, S. PONS, M. W. ANDERSON, L. J. LI, and M. HAWKINS, "Calorimetry of the Palladium-Heavy Water System," J. Electroanal. Chem., 298, 293 (1990); see also S. PONS and M. FLEISCHMANN, "The Calorimetry of Electrode Reactions and Measurements of Excess Enthalpy Generation in the Electrolysis of $\mathrm{D}_{2} \mathrm{O}$ Using Pd-Based Electrodes," Proc. 2nd Annual Conf. Cold Fusion, Como, Italy, June 29-July 4, 1991, p. 349.

3. L. L. ZAHM, A. C. KLEIN, S. E. BINNEY, J. N. REYES, Jr., J. F. HIGGINBOTHAM, and A. H. ROBINSON, "Experimental Investigations of the Electrolysis of $\mathrm{D}_{2} \mathrm{O}$ Using Palladium Cathodes and Platinum Anodes," J. Electroanal. Chem., 281, 313 (1990); see also A. C. KLEIN et al., "Anomalous Heat Output from Pd Cathodes without Detectable Nuclear Products," Proc. Anomalous Nuclear Effects in Deuterium/Solid Systems, Provo, Utah, October 22-23 1990.

4. M. C. H. McKUBRE, R. C. ROCHA-FILHO, S. SMEDLEY, F. TANZELLA, J. CHAD, B. CHEXAL, T. PASSELL, and J. SANTUCCI, "Calorimetry and Electrochemistry in the D/Pd System," Proc. 1st Annual Conf. ColdFusion, Salt Lake City, Utah, March 28-31, 1990, p. 20, National Cold Fusion Institute (1990); see also J. CHAO, W. LAYMEN, C. M. KANG, T. GUR, M. SCHREIBER, R. HUGGINS, G. LUCIER, and J. FERRANTE, "Three-Dimensional Computer Simulation of an Isoperibolic Calorimeter for Cold Fusion Experiments," Proc. 1st Annual Conf. Cold Fusion, Salt Lake City, Utah, March 28-31, 1990, p. 308, National Cold Fusion Institute (1990); see also M. C. H. McKUBRE, R. ROCHA-FILHO, S. T. SMEDLEY, F. L. TANZELLA, S. CROUCH-BAKER, T. O. PASSELL, and J. SANTUCCI, "Isothermal Flow Calorimetric Investigations of the D/Pd System," Proc. 2nd Annual Conf. Cold Fusion, Como, Italy, June 29-July 4, 1991, p. 349.

5. A. J. APPLEBY, Y. J. KIM, O. J. MURPHY, and S. SRINIVASAN, “Anomalous Calorimetric Results During Long-Term Evolution of Deuterium on Palladium from Alkaline Deuter-oxide Electrolyte," Proc. 1st Annual Conf. ColdFusion, Salt Lake City, Utah, March 28-31, 1990, p. 32, National Cold Fusion Institute (1990); see also S. SRINIVASAN, Y. J. KIM, O. J. MURPHY, C. R. MARTIN, and A. J. APPLEBY, "Evidence for Excess Heat Generation Rates During Electrolysis of $\mathrm{D}_{2} \mathrm{O}$ in LiOD Using a Palladium Cathode: A Microcalorimetric Study," presented at Workshop on Cold Fusion Phenomena, Santa Fe, New Mexico, May 23-25, 1989, LA-11686-C, Los Alamos National Laboratory (1989).

6. D. P. HUTCHINSON, C. A. BENNETT, R. K. RICHARDS, J. BULLOCK IV, and G. L. POWELL, "Initial Calorimetry Experiments in the Physics Division at ORNL," Proc. 1st Annual Conf. ColdFusion, Salt Lake City, Utah, March 28-31, 1990, National Cold Fusion Institute (1990); see also ORNL/TM-11356 and \#Y/DZ-490, Oak Ridge National Laboratory; see also G. L. POWELL, J. S. BULLOCK IV, R. L. HALLMAN, P. J. HOR-TON, and D. P. HUTCHINSON, “The Preparation of Palladium for Cold Fusion Experiments,” J. Fusion Energy, 9, 355 (1990).

7. M. SCHREIBER, T. M. GUR, G. LUCIER, J. A. FER-RANTE, J. CHAO and R. A. HUGGINS, "Recent Measurements of Excess Energy Production in Electrochemical Cells Containing Heavy Water and Palladium," Proc. 1st Annual Conf. Cold Fusion, Salt Lake City, Utah, March 28-31, 1990, p. 44, National Cold Fusion Institute (1990); see also M. SCHREIBER, T. M. GUR, G. LUCIER, J. A. FERRANTE, and R. A. HUGGINS, "Recent Experimental Results on the Thermal Behavior of Electrochemical Cells in the Hydrogen-Palladium and DeuteriumPalladium Systems," Proc. Cold Fusion Symp., 8th World Hydrogen Energy Conf., Honolulu, Hawaii, July 22-27, 1990, p. 71, University of Hawaii; see also T. M. GUR, M. SCHREIBER, G. LUCIER, J. A. FERRANTE, J. CHAO, and R. A. HUGGINS, "Experimental Considerations in Electrochemical Isoperibolic Calorimetry," Proc. 1st Annual Conf. Cold Fusion, Salt Lake City, Utah, March 28-31, 1990, p. 82, National Cold Fusion Institute 
(1990); see also A. BELZNER, U. BISCHLER, S. CROUCH-BAKER, T. M. GUR, M. SCHREIBER, and R. A. HUGGINS, "Two Fast Mixed Conductor Systems: Deuterium and Hydrogen and Palladium-Thermal Measurements and Experimental Considerations," presented at Workshop on Cold Fusion Phenomena, Santa Fe, New Mexico, May 23-25, 1989, and published in LA-11686-C, Los Alamos National Laboratory (1989), J. Fusion Energy, 9, 219 (1990), and Solid State Ionics, 40/41, 519 (1990).

8. C. D. SCOTT, J. E. MROCHEK, T. C. SCOTT, G. E. MICHAELS, E. NEWMAN, and M. PETEK, "Measurement of Excess Heat and Apparent Coincident Increases in the Neutron and Gamma-Ray Count Rates During the Electrolysis of Heavy Water," Fusion Technol., 18, 103 (1990); see also C. D. SCOTT, J. E. MROCHEK, T. C. SCOTT, G. E. MICHAELS, E. NEWMAN, and M. PETEK, "Initiation of Excess Power and Possible Products of Nuclear Interactions During the Electrolysis of Heavy Water," Proc. 1st Annual Conf. Cold Fusion, Salt Lake City, Utah, March 28-31, 1990, p. 164, National Cold Fusion Institute (1990) and TM-11322, Oak Ridge National Laboratory; see also C. D. SCOTT, E. GREENBAUM, G. E. MICHAELS, J. E. MROCHEK, E. NEWMAN, M. PETEK, and T. C. SCOTT, "Preliminary Investigation of Possible Low Temperature Fusion," presented at Workshop on Cold Fusion Phenomena, Santa Fe, New Mexico, May 23-25, 1989, and published in LA11686-C, Los Alamos National Laboratory (1989), and J. Fusion Energy, 9, 115 (1990).

9. L. J. DROEGE and T. F. DROEGE, "A Zero Gradient Calorimeter for the Measurement of Anomalous Heat from the Electrolysis of Deuterated Metals," Proc. 1st Annual Conf. Cold Fusion, Salt Lake City, Utah, March 28-31, 1990, p. 229, National Cold Fusion Institute (1990); see also T. F. DROEGE, "A Discussion of an $\mathrm{H}_{2} \mathrm{O}$ Run Which Followed Operation with $\mathrm{D}_{2} \mathrm{O}$," SMATN-90-2, Environmental Optics Corporation, Batavia, Illinois (Apr. 1990).

10. D. GOZZI, P.L. CIGNINI, L. PETRUCCI, M. TOMEL-LINI, and G. DE MARIA, "Evidences for Associated Heat Generation and Nuclear Products Release in Palladium Heavy-Water Electrolysis," presented at Workshop on Cold Fusion Phenomena, Santa Fe, New Mexico, May 23-25, 1989, and published in LA-11686-C, Los Alamos National Laboratory (1989), and Nuovo Cimento, 103, 143 (1990); see also D. GOZZI, P. L. CIGNINI, L. PETRUCCI, M. TOMELLINI, G. DE MARIA, S. FRULLANI, F. GARIBALDI, F. OHIO, M. JODICE, and E. TABET, "Nuclear and Thermal Effects During Electrolytic Reduction of Deuterium at Palladium Cathode," $J$. Fusion Energy, 9, 241 (1990); see also D. GOZZI, P. L. CIGNINI, and M. TOMELLINI, "Multicell Experiments for Searching Time-Related Events in Cold Fusion," Proc. 2nd Annual Conf. Cold Fusion, Como, Italy, June 29July 4, 1991, p. 21.

11. R. C. KAINTHLA, O. A. VELEV, L. KABA, G. H. LIN, N. PACKHAM, J. BOCKRIS, M. SKLARZYK, and J. WASS, "Sporadic Observation of the Fleischmann-Pons Effect," Electrochim. Acta, 34, 1315 (1989); see also O. A. VELEV and R. C. KAINTHLA, "Heat Flow Calorimeter with a Personal-Computer-Based Data Acquisition System," Fusion Technol., 18, 351 (1990).

12. R. T. BUSH, “Cold 'Fusion': The Transmission Resonance Model Fits Data on Excess Heat, Predicts Optimal 'Trigger' Points, and Suggests Nuclear-Reaction Scenarios,' Fusion Technol., 19, 313 (1991); see also R. T. BUSH, “The TRM (Transmission Resonance Model) for Cold 'Fusion' Fits Calorimetric Data on the Pons-Fleischmann Effect and Suggests Solutions to Nuclear 'Anomalies, "'Proc. Cold Fusion Symp., 8th World Hydrogen Energy Conf., Honolulu, Hawaii, July 22-27, 1990, University of Hawaii; see also R. D. EAGLETON and R. T. BUSH, "Design Considerations on Electrodes as Suggested by a Deuterium Cluster Model for Cold Nuclear Fusion," $J$. Fusion Energy, 9, 359 (1990); see also R. T. BUSH and R. D. EAGLETON, “ 'Cold Nuclear Fusion’: A Hypothetical Model to Probe an Elusive Phenomenon,” J. Fusion Energy, 9, 397 (1990).

13. B. Y. LIAW, P.-L. TAO, P. TURNER, and B. E. LIEBERT, "Elevation Temperature Excess Heat Production Using Molten Salt Electrochemical Techniques," Proc. Cold Fusion Symp., 8th World Hydrogen Energy Conf., Honolulu, Hawaii, July 22-27, 1990, University of Hawaii; see also B. Y. LIAW, P.-L. TAO, P. TURNER, and B. E. LIEBERT, "Elevated-Temperature Excess Heat Production in a Pd-D System," J. Electroanal. Chem., 319,161 (1991); see also B. Y. LIAW, P.-L. TAO, and B. E. LIE-BERT, "Recent Progress on Cold Fusion Research Using Molten Salt Techniques," Proc. 2nd Annual Conf. Cold Fusion, Como, Italy, June 29-July 4, 1991, p. 55.

14. C. S. YANG, C. Y. LIANG, T. P. PERNG, L. J. YUAN, C. M. WAN, and C. C. WAN, "Observations of Excess Heat and Tritium on Electrolysis of $\mathrm{D}_{2} \mathrm{O}$," Proc. Cold Fusion Symp., 8th World Hydrogen Energy Conf., Honolulu, Hawaii, July 22-27, 1990, p. 95, University of Hawaii. 
15. A. B. KARABUT, Ya. R. KUCHEROV, and I. B. SAVATI-MOVA, "Cold Fusion Observations at GasDischarge Device Cathode," presented at Specialists' Conf. Nuclear Power Engineering in Space, Obninsk, USSR, May 15-19, 1990.

16. V. C. NONINSKI and C. I. NONINSKI, "Determination of the Excess Energy Obtained During the Electrolysis of Heavy Water,” Fusion Technol., 19, 364 (1991).

17. R. A. ORIANI, J. C. NELSON, S. LEE, and J. H. BROAD-HURST, “Calorimetric Measurements of Excess Power Output During the Cathodic Charging of Deuterium into Palladium,” Fusion Technol., 18, 652 (1990).

18. K. S. V. SANTHANAM, J. RANGARAJAN, O’N. BRAGANZA, S. K. HARAM, N. M. LIMAYE, and K. C. MAN-DAL, "Electrochemically Initiated Cold Fusion of Deuterium," Indian J. Technol., 27, 175 (1989).

19. M. H. MILES, K. H. PARK, and D. E. STILWELL, "Electrochemical Calorimetric Evidence for Cold Fusion in the Palladium-Deuterium System,” J. Electroanal. Chem., 296, 241 (1990); see also B. F. BUSH, J. J. LAGOWSKI, M. H. MILES, and G. S. OSTROM, "Helium Production During the Electrolysis of $\mathrm{D}_{2} \mathrm{O}$ in Cold Fusion," J. Electroanal. Chem., 304, 271 (1991); see also M. H. MILES, B. F. BUSH, G. S. OSTROM, and J. J. LAGOWSKI, "Heat and Helium Productions in Cold Fusion Experiments," Proc. 2nd Annual Conf. Cold Fusion, Como, Italy, June 29-July 4, 1991, p. 363.

20. Y. ARATA and Y. ZHANG, “Achievement of an Intense Cold Fusion Reaction,” Fusion Technol., 18, 95 (1990), and Proc. Jpn. Acad. B, 66, 1 (1990); see also Y. ARATA and Y. ZHANG, "Cold Fusion Caused by a Weak On-Off Effect," Proc. Jpn. Acad. B, 66, 33 (1990).

21. D. LEWIS and K. SKOLD, "A Phenomenological Study of the Fleischmann-Pons Effect,” J. Electroanal. Chem., 294, 275 (1990).

22. S. GURUSWAMY and M. E. WADSWORTH, "Metallurgical Aspects in Cold Fusion Experiments," Proc. 1st Annual Conf. Cold Fusion, Salt Lake City, Utah, March 28-31, 1990, p. 314, National Cold Fusion Institute (1990).

23. S. SZPAK, P. A. MOSIER-BOSS, and J. J. SMITH, "On the Behavior of Pd Deposited in the Presence of Evolving Deuterium,” J. Electroanal. Chem., 302, 255 (1991).

24. N. HUANG, Q. H. GAO, B. Y. LIAW, and B. E. LIEBERT, “A Flow Calorimeter Used in Duplication of 'Cold Fusion," presented at Special Session Cold Fusion, Electrochemical Society Mtg., Hollywood, Florida, October 20, 1989.

25. R. D. EAGLETON and R. T. BUSH, "Calorimetric Experiments Supporting the Transmission Resonance Model for Cold Fusion,” Fusion Technol., 20, 239 (1991).

26. R. T. BUSH, "Excess Heat Production from a Cold Fusion Cell Using a Cathode of Silver Coated with a Thin Layer of Palladium,” California State Polytechnic University, Private Communication (1991).

27. H. IKEGAMI, “Cold Fusion Research in Japan,” Proc. 2nd Annual Conf. Cold Fusion, Como, Italy, June 29July 4, 1991, p. 297.

28. F. G. WILL, K. CEDZYNSKA, M.-C. YANG, J. R. PETERSON, J. E. BERGESON, S. C. BARROWES, W. J. WEST, and D. C. LINTON, "Studies of Electrolytic and Gas Phase Loading of Palladium with Deuterium," Proc. 2nd Annual Conf. Cold Fusion, Como, Italy, June 29-July 4, 1991, p. 297.

29. E. STORMS and C. TALCOTT-STORMS, "The Effect of Hydriding on the Physical Structure of Palladium and on the Release of Contained Tritium," Proc. Anomalous Nuclear Effects in Deuterium/Solid Systems, Provo, Utah, October 22-23, 1990, and Fusion Technol., 20, 246 (1991). 
30. E. STORMS, "Review of Experimental Observations About the Cold Fusion Effect," Fusion Technol., 20, 433 (1991). 